\title{
The Practice of Practical Education: Male Students and Female Apprentices in the Lying-in Hospital of Göttingen University, 1792-1815
}

\author{
JÜRGEN SCHLUMBOHM*
}

It is generally agreed that, in most European countries, practical education became increasingly important for future physicians and surgeons during the course of the eighteenth century. Recent studies have shown that, around 1800, clinical teaching took place in a variety of contexts: hospitals with inpatients, polyclinics or outpatient dispensaries, consultation hours for poor people, private tutoring by, or a kind of apprenticeship with, an experienced practitioner. ${ }^{1}$ While these organizational forms have become fairly clear in several countries, much less is known about what "practical" training actually meant. Did it mainly consist of "studying written case histories", ${ }^{2}$ or following "clinical lectures" in the classroom where the teacher brought in patients and explained their diseases? Did students attend the hospital rounds of professors and hospital physicians, or did they "walk the wards" on their own? To what extent were medical students allowed to question patients, and physically examine them? Were they given responsibility for patients under the supervision of a professor or an experienced physician? If so, how many patients did they examine or treat during their education? It is true that we know the regulations of some medical schools at specific points in time, but we have much less knowledge about how these rules were implemented. The few surviving memoirs, diaries and travel accounts make clear that there may have been a considerable gap between norms and practice. A major constraining factor was of course the number of students per patient, and per teacher.

Detailed archival and printed sources from the lying-in hospital of Göttingen University allow a deeper insight into the practice of clinical teaching during the late eighteenth and early nineteenth centuries. In this period, when midwifery was being transformed into

(C) Jürgen Schlumbohm 2007

*Jürgen Schlumbohm, Max-Planck-Institut für Geschichte, Postfach 2833, D-37018 Göttingen, Germany; schlumbohm@mpi-g.gwdg.de

The author thanks Birgitt Sippel and Nadine Schillig for their help in building and analysing the database used in this article. He is grateful to Caroline Tonson-Rye for revising his English and to Vivian Nutton for checking his translations of German quotations.

${ }^{1}$ Thomas Neville Bonner, Becoming a physician: medical education in Britain, France, Germany, and the United States, 1750-1945, New York, Oxford University Press, 1995; Othmar Keel, L'avènement de la médecine clinique moderne en Europe: 1750-1815, Montreal, Presses de 1'Université de Montréal, 2001; see also Harm Beukers and J Moll (eds), Clinical teaching: past and present, Amsterdam, Rodopi, 1989; Vivian Nutton and Roy Porter (eds), The history of medical education in Britain, Amsterdam, Rodopi 1995; L W B Brockliss, 'Before the clinic: French medical teaching in the eighteenth century', in Caroline Hannaway and Ann La Berge (eds), Constructing Paris medicine, Amsterdam, Rodopi, 1998, pp. 71-115; Mary Lindemann, Medicine and society in early modern Europe, Cambridge University Press, 1999, pp. 92-119.

${ }^{2}$ Lisa Rosner, 'Eighteenth-century medical education and the didactic model of the experiment', in Peter R Dear (ed.), The literary structure of scientific argument: historical studies, Philadelphia, University of Pennsylvania Press, 1991, pp. 182-94, on p. 191. For other forms of practical teaching, see Lisa Rosner, Medical education in the age of improvement:

Edinburgh students and apprentices 1760-1826, Edinburgh University Press, 1991. 


\section{Jürgen Schlumbohm}

a branch of medical science, access to practical experience was of particular importance. Males, physicians or surgeons, could compete successfully with female midwives only if they acquired practical skills in addition to the superior theoretical knowledge which they claimed. Midwives, on the other hand, had free access to practice and were usually trained by an informal apprenticeship with an older midwife. But, according to many medical men, they were ignorant because they lacked any theoretical knowledge. ${ }^{3}$ In Germany, where medical education continued to be centred mainly on universities, ${ }^{4}$ the lying-in hospitals attached to them were of crucial importance for the rise of man-midwifery. The maternity hospital of Göttingen University, founded in 1751, played a pioneer role. ${ }^{5}$ The University, a foundation of the Enlightenment, had tried to include bedside teaching from its beginnings in the 1730s because its medical faculty was aware that this was a prime factor in attracting students. The maternity school of 1751, however, was its first clinical institution; a general infirmary was opened only in $1781 .^{6}$ In the early days, under the directorship of Professor Johann Georg Roederer (1726-63), the lying-in service consisted of just two rooms in a hospital which mainly housed elderly persons, and the number of deliveries was usually less than 30 per year. In the 1780 s, the University persuaded the government to have the old building pulled down and replaced by a spacious new structure, earmarked exclusively for the maternity hospital. On the first floor, there were seven chambers for a total of fourteen patients, the delivery room, the teaching hall, and the hospital midwife's accommodation. The second floor housed the director and his family; while the manager and his family, the servant and the midwife apprentices lived on the ground floor. The new house opened in 1791, and in 1792, a new professor of obstetrics and hospital director was called to Göttingen. Friedrich Benjamin Osiander (1759-1822), trained in Tübingen, Strasbourg and Kassel, held office until his death. In the new building, the annual number of deliveries rose to between 70 and 100 .

Osiander was outspoken about the hospital's order of priorities: "The lying-in hospital at Göttingen aims, above all, to train skilful obstetricians ... secondly, to train midwives ... and finally, to provide a safe shelter for poor pregnant women, married or not, during the period of childbirth ..."?

To what extent were students and midwives attracted by this offer?

\footnotetext{
${ }^{3}$ On the meaning of this reproach, see Waltraud Pulz, "Nicht alles nach der Gelahrten Sinn geschrieben”. Das Hebammenanleitungsbuch von Justina Siegemund, Munich, Münchener Vereinigung für Volkskunde, 1994, pp. 117-136; eadem, 'Aux origines de l'obstétrique moderne en Allemagne (XVIe-XVIIIe siècle): accoucheurs contre matrones?', Revue d' histoire moderne et contemporaine, 1996, 43 (4): 593-617.

${ }^{4}$ Thomas H Broman, The transformation of German academic medicine, 1750-1820, Cambridge University Press, 1996, pp. 26-66.

${ }^{5}$ Jürgen Schlumbohm, "“The pregnant women are here for the sake of the teaching institution": the lyingin hospital of Göttingen University, 1751 to c.1830', Soc. Hist. Med., 2001, 14: 59-78.

${ }^{6}$ Isabelle von Bueltzingsloewen, Machines à instruire, machines à guérir: les hôpitaux
}

universitaires et la médicalisation de la société allemande, 1730-1850, Lyon, Presses universitaires de Lyon, 1997, pp. 101-19; Axel Karenberg, Lernen am Bett der Kranken: die frühen Universitätskliniken in Deutschland (1760-1840), Hürtgenwald, Pressler, 1997, pp. 42-45, 95-105.

${ }^{7}$ Friedrich Benjamin Osiander, Annalen der Entbindungs-Lehranstalt auf der Universität zu Göttingen vom Jahr 1800, 2 vols in 4 parts, Göttingen, Dieterich, 1800-1804, vol 1, part 1, p. IX: "Das Entbindungs-Hospital in Göttingen hat ganz besonders den Zweck, dass daran ... geschickte ... Geburtshelfer gebildet werden. Ein zweiter Zweck ist, dass auch Hebammen ... darin gebildet werden ... Ein dritter Zweck endlich ist, dass arme, eheliche und uneheliche Schwangere eine sichere Unterkunft über die Zeit ihrer Geburt ... finden ....". In quotations, I have modernized the punctuation and spelling. Where, 


\section{The Practice of Practical Education}

\section{The Lying-in Hospital: An Attraction for Medical Students}

The University of Göttingen of the Electorate of Hanover was not only the most recent foundation (1734/37) among German universities-rivalling Halle (in Prussia, founded in 1694) as the most modern ${ }^{8}$ - but it was also among the largest. During the eighteenth century, it was one of the top four in terms of student numbers, together with Halle, Jena and Leipzig, and for some years in the early nineteenth century it even became the largest of them all. ${ }^{9}$ In the 1790 s, the total number of students at Göttingen averaged over 700, and in 1815 it was more than $800 .{ }^{10}$ The medical faculty, too, was among the most important in Germany in terms of numbers of students (more than 100 in the 1790s: see Table 1, col. 1), MD degrees awarded (a total of almost 200 in the decade 1790-99), and full professors (eight in 1796). ${ }^{11}$ Like the other faculties, it was able to attract many young men from "abroad", i.e. from other German states, as well as from foreign countries including Russia, Switzerland and England. ${ }^{12}$

Out of this large number of medical students, how many were interested in the relatively new speciality of obstetrics? As Table 1 (cols. 1 and 3) shows, during each semester in the 1790 s an average of one-third (32.5 per cent) of all the medical students "used" the lyingin hospital, and in 1815 close to half (43.6 per cent). This figure is surprisingly high, but can in part be explained by the fact that around 1800 in Germany students tended to stay for only about two years at a specific university. ${ }^{13}$ Some moved from one university to another, but many appear to have studied for only a relatively short time, since there were no established curricula, and few final exams or formal requirements for graduation in terms of expert knowledge. This was true of the medical faculty of Göttingen, as well, ${ }^{14}$ and there, too, students spent an average of four semesters in the 1790s (Table 1: ratio between col. 1 and col. 2). Those who received an MD from Göttingen University in the last decade of the eighteenth century had spent there on average less than a year and a half. ${ }^{15}$

For some semesters, Osiander's list of students specified how many attended his course for the first time and how many were repeaters (Table 1, col. 4). The proportion of the latter

however, words were pronounced differently than in modern standard German, I have kept the original spelling. The translations from German and Latin sources are mine.

${ }^{8}$ William Clark, Academic charisma and the origins of the research university, University of Chicago Press, 2006, pp. 377-97; Johanna

Geyer-Kordesch, 'German medical education in the eighteenth century: the Prussian context and its influence', in W F Bynum and Roy Porter (eds), William Hunter and the eighteenth-century medical world, Cambridge University Press, 1985, pp. 177-205. In the nineteenth century, Berlin University, founded in 1810 , became predominant.

${ }^{9}$ Franz Eulenburg, Die Frequenz der deutschen Universitäten von ihrer Gründung bis zur Gegenwart, Leipzig, Teubner, 1904, pp. 145-51, 182-5. Austrian universities are not included.

${ }^{10}$ Norbert Kamp (ed.), 250 Jahre Georg-AugustUniversität Göttingen: Studentenzahlen 1734/37-1987, Göttingen, Goltze [c. 1987], pp. 2-3;
Hartmut Titze, et al., Wachstum und Differenzierung der deutschen Universitäten 1830-1945, Göttingen, Vandenhoeck \& Ruprecht, 1995, p. 232.

${ }^{11}$ Eulenburg, op. cit., note 9 above, pp. 153, 313, 319; E Th Nauck, 'Die Zahl der Medizinstudenten deutscher Hochschulen im 14.-18. Jahrhundert', Sudhoffs Archiv, 1954, 38: 175-86, pp. 182, 184; Ulrich Tröhler and Sabine Mildner-Mazzei, Vom Medizinstudenten zum Doktor: die Göttinger Medizinischen Promotionen im 18. Jahrhundert, Göttingen, Vandenhoeck \& Ruprecht, 1993, pp. 10-15.

${ }^{12}$ Tröhler and Mildner-Mazzei, op. cit., note 11 above, pp. 16-21, 41.

${ }^{13}$ Eulenburg, op. cit., note 9 above, pp. 181-2.

${ }^{14}$ Tröhler and Mildner-Mazzei, op. cit., note 11 above, pp. 21-31.

${ }^{15}$ Ibid., p. 41. In earlier decades, the period was twice as long. It was clearly longer in Edinburgh, Rosner, Medical education, op. cit., note 2 above, pp. 68-9. 


\section{Jürgen Schlumbohm}

\section{Table 1}

Number of students at the medical faculty of Göttingen University, number of students and of midwives using the lying-in hospital, 1792-1801 and 1815

\begin{tabular}{|c|c|c|c|c|c|}
\hline \multirow[t]{3}{*}{ Semester } & \multicolumn{2}{|c|}{$\begin{array}{l}\text { Number of students } \\
\text { at the medical faculty }\end{array}$} & \multicolumn{3}{|c|}{ Number of users of the lying-in hospital } \\
\hline & \multirow[t]{2}{*}{ Total number } & \multirow{2}{*}{$\begin{array}{c}\text { out of whom newly } \\
\text { matriculated }\end{array}$} & \multicolumn{2}{|c|}{ Medical students } & \multirow{2}{*}{$\begin{array}{c}\text { Midwives } \\
\text { First/second } \\
\text { quarters }^{2}\end{array}$} \\
\hline & & & Total number ${ }^{1}$ & Repeaters & \\
\hline & (1) & (2) & (3) & (4) & $(5)$ \\
\hline WS 1792/93 & 110 & 35 & 21 & $-*$ & $-/ 4$ \\
\hline SS 1793 & 114 & 23 & 36 & 8 & $2 /-$ \\
\hline WS 1793/94 & 116 & 29 & 24 & 6 & $1 /-$ \\
\hline SS 1794 & 108 & 25 & 18 & - & $-1-$ \\
\hline WS 1794/95 & 103 & 22 & 27 & 7 & $-1-$ \\
\hline SS 1795 & 102 & 26 & 30 & 10 & $-1-$ \\
\hline WS $1795 / 96$ & 114 & 25 & 40 & 17 & $-/ 2$ \\
\hline SS 1796 & 118 & 28 & 49 & 13 & $2 /-$ \\
\hline WS 1796/97 & 105 & 26 & 47 & - & $5 / 6$ \\
\hline SS 1797 & 114 & 26 & 39 & - & $2 / 0$ \\
\hline WS 1797/98 & 110 & 32 & 41 & - & $2 / 2$ \\
\hline SS 1798 & 110 & 28 & 31 & - & $-1-$ \\
\hline WS $1798 / 99$ & 113 & 28 & 41 & - & $4 / 4$ \\
\hline SS 1799 & 103 & 30 & 47 & - & $4 / 4$ \\
\hline WS $1799 / 1800$ & 104 & 20 & 28 & 17 & $3 / 3$ \\
\hline SS 1800 & 106 & 26 & 48 & 15 & $8 / 1$ \\
\hline WS 1800/01 & 100 & 25 & 35 & 20 & $1 /-$ \\
\hline Subtotal & 1,850 & 454 & 602 & & \\
\hline WS $1814 / 15$ & 145 & - & 65 & - & \\
\hline SS 1815 & 136 & - & 60 & - & $16^{3}$ \\
\hline W 1815/16 & 146 & - & 61 & - & \\
\hline Subtotal & 427 & & 186 & & \\
\hline
\end{tabular}

*Dashes indicate that these numbers are not available.

${ }^{1}$ The source gives the number of students per quarter (three-month period). In most cases, the number was the same for both quarters, or given for only one of the two quarters. For the three semesters where the numbers for the two quarters differed by one, the table gives the higher figure. For the two semesters where the numbers of the two quarters differed by two, and for one semester, where the numbers of the two quarters differed by four, the table gives the average.

${ }^{2}$ The courses for midwives usually lasted three months. Since we do not know the exact dates in most years, it is difficult to tell to what extent the same midwives are counted as using the lying-in hospital, in two subsequent quarters. Cf. note 103 of the text.

${ }^{3}$ The source gives a total of 16 midwives for the whole of 1815 . 


\section{The Practice of Practical Education}

Table 1 (continued)

Sources:

Col. 1: Norbert Kamp (ed.), 250 Jahre Georg-August-Universität Göttingen: Studentenzahlen 1734/37-1987, Göttingen, Goltze [c.1987], p. 29; Hartmut Titze et al., Wachstum und Differenzierung der deutschen Universitäten 1830-1945, Göttingen, Vandenhoeck \& Ruprecht, 1995, p. 232.

Col. 2: My own calculation, based on: Götz von Selle (ed.), Die Matrikel der Georg-AugustUniversität zu Göttingen 1734-1837, Hildesheim, Lax, 1937, pp. 338-412. I have counted those enrolled 1 March to 31 August as newly matriculated for the summer semester (SS, 1 April-30 September), and those enrolled 1 September-28 (29) February for the winter semester (WS, 1 October-31 March).

Cols. 3 and 5: AUFK Gö, O 3: Friedrich Benjamin Osiander, 'Sammlung der vierteljährigen Übersichten der Königlichen Entbindungsanstalt zu Göttingen', 1785-1800; for 1815: Friedrich Benjamin Osiander, Übersicht über die Ereignisse in der Entbindungslehranstalt im Jahr 1815, Göttingen, Huth, 1816, pp. 14-15.

Col. 4: AUFK Gö, W 29: Ankündigung von Lehrveranstaltungen, 1790-1797, fols. 8-9, 16-17, 23-24, 27-28; Friedrich Benjamin Osiander, Kurze Übersicht der Vorfälle in dem Königl. Entbindungshospital auf der Georg-Augustus-Universität zu Göttingen vom 1. Octob. 1794 bis 23. März 1795 [...], Göttingen, (no date, no publisher given), p. [1]; idem, Kurze Übersicht der Vorfälle in dem Königl. Entbindungshospital auf der Georg-AugustusUniversität zu Göttingen vom 1. April bis 31.[sic] September 1795 [...], Göttingen, (no date, no publisher given), p. [1]; AUFK Gö, A 1: Tagebuch, vol. 4, 1795-1797, fols. [364]-[365]; Friedrich Benjamin Osiander, Annalen der Entbindungs-Lehranstalt auf der Universität zu Göttingen vom Jahr 1800, 2 vols. in 4 parts, Göttingen, Dieterich, 18001804, vol. 1, part 1, pp. 164-6, vol. 1, part 2, pp. 91-5, vol. 2, part 2, pp. 320-1.

amounted to more than a third of the total number of participants in those semesters (113 out of 317, i.e. 35.6 per cent). Therefore, the total of 602 students (col. 3), when corrected for repeaters, probably implies about 387 individuals. Thus the overwhelming majority of the students enrolled at the medical faculty did in fact use the lying-in hospital: 387 out of 454 (col. 2), that is 85 per cent. ${ }^{16}$

As this figure shows, Osiander had good reason to argue that his lying-in hospital was a major asset of the University's medical faculty and helped considerably to attract both German and foreign students. ${ }^{17}$ The fact that attendance at his course was so high is particularly remarkable, since in many German states there were no formal requirements of this kind, neither for graduation, nor for admission by public authorities as a practitioner. ${ }^{18}$

\footnotetext{
${ }^{16}$ On the other hand, I have found 23 male birth attendants in the hospital case books and calendars who seem not to have matriculated, since they do not appear in Götz von Selle (ed.), Die Matrikel der Georg-AugustUniversität zu Göttingen, 1734-1837, Hildesheim, Lax, 1937. If they are subtracted from 387, still 80 per cent out of the 454 students matriculated used the lyingin hospital. In Edinburgh, only 27 per cent of the students attended the course in midwifery during the late eighteenth and early nineteenth centuries: Rosner, Medical education, op. cit., note 2 above, p. 55.
}

\footnotetext{
${ }^{17}$ Tröhler and Mildner-Mazzei, op. cit., note 11 above, p. 40.

${ }^{18}$ Hans-Christoph Seidel, Eine neue 'Kultur des Gebärens' : die Medikalisierung von Geburt im 18. und 19. Jahrhundert in Deutschland, Stuttgart, Steiner, 1998, pp. 280-2; see also I[sidor] Fischer, Geschichte der Geburtshilfe in Wien, Leipzig, Deuticke, 1909, pp. 149-57; Tröhler and Mildner-Mazzei, op. cit., note 11 above, pp. 22-49.
} 


\section{Jürgen Schlumbohm}

It appears that the faculty relied on the students' own interest in a good education as the best way to achieve success in practice.

For how long did the students participate in the courses at the maternity hospital? Osiander reported that, during nine semesters between summer 1793 and winter 1800/01, out of a total of 313 students, 200 attended for the first time, 90 for the second, 15 for the third, 5 for the fourth, and 3 for even the fifth time. On this basis, the estimate is that the majority ( 55 per cent) of the students attended his course for only one semester, but more than a third (37.5 per cent) for two semesters, 5 per cent for three semesters, and 2.5 per cent for four or even five semesters. ${ }^{19}$

These figures show that the medical faculty of Göttingen attracted high numbers of students partly because of the importance of the lying-in hospital. Almost all the medical students enrolled in Göttingen made use of it, although a majority for only one semester. There was a minority of medical students, however, who were eager to get a more extensive training in midwifery.

As for the training of female midwives, the figures clearly seem to show that this was much less important than the education of male students (Table 1, col. 5). Usually between two and six women participated in the course, that is about one-tenth of the number of medical students. The course for midwives lasted three months, generally from May to July, and from December to February. ${ }^{20}$ As early as 1752 , just six months after the lying-in hospital opened, the government of Hanover had ordered that towns should not accept any new midwives unless they had been taught at the maternity hospital and examined by the professor of obstetrics. ${ }^{21}$ This would have created a strong incentive for women to attend the course, in particular if towns followed the advice of the government and paid the cost of their midwives' stay at Göttingen. It appears, however, that it took a long while before this ordinance was fully implemented in all towns, and even longer before rural communities followed suit. ${ }^{22}$

\section{"A Complete Course on the Theoretical and Practical Parts of Midwifery"}

"Every semester a complete course on the theoretical and practical parts of midwifery is held", Professor Osiander told the medical reading public. ${ }^{23}$ What

\footnotetext{
${ }^{19}$ This estimate is based on the fictive assumption that in these figures we are always dealing with the same group of students. Under this assumption, those students who attended the course for the second time, are included among those who attended for the first time in the previous semester, and those who attended for the third time are included among those who attended for the second time in the previous semester, and among those who attended for the first time in the second to the last semester, etc. Accordingly, the estimate is that we are dealing with 200 different students, out of whom 110 attended the course for only one semester, 75 for two semesters, 10 for three semesters, 2 for four semesters, and 3 for five semesters.

${ }^{20}$ Osiander, Annalen, op. cit., note 7 above, vol. 1, part 1, 1800, p. XI.

${ }^{21}$ Universitätsarchiv Göttingen (hereafter UnivA Gö), Kur. 5406, fols 1-4, dated 17 June 1752. See also
}

Friedrich Benjamin Osiander, Denkwürdigkeiten für die Heilkunde und Geburtshülfe aus den Tagebüchern der Königlichen practischen Anstalten zu Erlernung dieser Wissenschaften in Göttingen ausgehoben, Göttingen, Vandenhoeck \& Ruprecht, 1794, vol.1, part 1, pp. CXVIII-CXX.

${ }^{22}$ Henrike Hampe, Zwischen Tradition und Instruktion: Hebammen im 18. und 19. Jahrhundert in der Universitätsstadt Göttingen, Göttingen, Schmerse, 1998, pp. 85-89, see also 47-59.

${ }^{23}$ Osiander, Denkwürdigkeiten, op. cit., note 21 above, vol. 1, part 1, p. CVI: "Jedes halbe Jahr wird ein vollständiger Cursus über den theoretischen und praktischen Teil der Geburtshülfe gehalten”. 


\section{The Practice of Practical Education}

this meant becomes clearer by his remark that he based his course on Stein's textbook. ${ }^{24}$ Georg Wilhelm Stein (senior), whom Osiander revered as his teacher, ${ }^{25}$ divided his manual into two parts Theoretische Anleitung zur Geburtshülfe (Theoretical Guide to Midwifery), and Practische Anleitung zur Geburtshülfe (Practical Guide to Midwifery), both explicitly designed as lecture textbooks. ${ }^{26}$ The first "theoretical" volume had chapters on the female genitals, pregnancy, the "fruit" or "embryo", and childbirth, in particular "natural childbirth". ${ }^{27}$ The second "practical" volume dealt with "contranatural and difficult cases", and had chapters on "manual" and "instrumental operations". ${ }^{28}$ Later, Osiander used his own Grundriss der Entbindungskunst zum Leitfaden bei seinen Vorlesungen (Outline of the Art of Accouchement ), published in 1802, ${ }^{29}$ for he believed that the development of the discipline during the previous decade made a more upto-date manual necessary. ${ }^{30}$ This text was also in two volumes, the first treating pregnancy and childbirth, and the second, delivery and instruments. ${ }^{31}$ The second "practical" part explained "what an accoucheur should and should not do in contranatural cases and in such cases of childbirth which require artificial assistance". ${ }^{32}$ It is no coincidence that Osiander, like most of his colleagues, in Germany at least, thought that artificial assistance in childbirth was reserved for the male sex, while female midwives should, in principle,

\footnotetext{
${ }^{24}$ Ibid. Osiander stressed that, although he followed the order of Stein's textbook, he added and changed wherever he found fit.

${ }^{25}$ In the winter of $1781 / 82$, when Osiander was already a practitioner at Kirchheim unter Teck in his native state of Württemberg, he took a private course with Stein in the town of Kassel, and, under Stein's direction, practised for five months in the lying-in hospital. Wilhelm Egenolf, 'Friedrich Benjamin Osiander, Ordentlicher Professor der Arzneiwissenschaft und Direktor der Kgl. Hannoverschen Entbindungsanstalt und des Instituti Clinici der Universität Göttingen von 1792-1822', Vorarbeiten zur Geschichte der Göttinger Universität und Bibliothek, 1937, 22: 31-58, on pp. 39-41. Georg Wilhelm Stein (1737-1803) had studied with Roederer in Göttingen and André Levret in Paris. In 1763 he became a professor in Kassel, and from 1766, in addition, the director of the maternity and foundling hospital. In 1789, he was appointed professor at the University of Marburg, and in 1792 director of the maternity hospital there. Christina Vanja, 'Das Kasseler Accouchier- und Findelhaus 1763-1787: Ziele und Grenzen "vernünftigen Mitleidens" mit Gebärenden und Kindern', in Jürgen Schlumbohm and Claudia Wiesemann (eds), Die Entstehung der Geburtsklinik in Deutschland 1751-1850: Göttingen, Kassel, Braunschweig, Göttingen, Wallstein, 2004, pp. 96-126, on pp. 103-110; Marita Metz-Becker, Der verwaltete Körper: die Medikalisierung schwangerer Frauen in den Gebärhäusern des frühen 19. Jahrhunderts, Frankfurt/Main, Campus, 1997, pp. 107-8.

${ }^{26}$ Georg Wilhelm Stein, Theoretische Anleitung zur Geburtshülfe: zum Gebrauche der Vorlesungen,
}

new ed., Marburg, Neue Akademische Buchhandlung, 1793 (1st ed.,1770); idem, Practische Anleitung zur Geburtshülfe: zum Gebrauche der Vorlesungen, new ed., Marburg, Neue Akademische Buchhandlung, 1793 (lst ed., 1772).

${ }^{27}$ Idem, Theoretische Anleitung, op. cit., note 26 above, p. 88: "Frucht (Embryo)"; pp. 165-220 "natürliche Geburt".

${ }^{28}$ Idem, Practische Anleitung, op. cit., note 26 above. On the unnumbered page following the table of contents, the book title is given as Practische Anleitung zur Geburtshülfe in widernatürlichen und schweren Fällen; pp. 96-143: "Von Manualoperationen ..."; pp. 190-264: "Von Instrumentaloperationen ....",

${ }^{29}$ This is mentioned in the list of courses at Göttingen University, e.g., in the winter semester 1803/04 and in the summer semester 1805: Göttingische Gelehrte Anzeigen (hereafter GGA), 1803, no. 146, 10 Sept. 1803, p. 1456; ibid., 1805, no. 51, 30 March 1805, p. 504. Friedrich Benjamin Osiander, Grundriss der Entbindungskunst zum Leitfaden bei seinen Vorlesungen, 2 vols, Göttingen, Dieterich, 1802.

${ }^{30}$ Osiander, Grundriss, op. cit., note 29 above, vol. 1, p. XI.

${ }^{31}$ Vol. 1 had the sub-title: Schwangerschafts- und Geburts-Lehre, vol. 2: Entbindungs- und WerkzeugeLehre.

${ }^{32}$ Osiander, Grundriss, op. cit., note 39 above, vol. 2, p. III: “. .. was ein Geburtshelfer bei widernatürlichen und die Hülfe der Kunst erfordernden Geburtsfällen zu tun und zu lassen hat"; p. V: “... in dem gegenwärtigen praktischen Teil ...". 


\section{Jürgen Schlumbohm}

be limited to assisting in "natural" deliveries. This was in line with a dichotomous notion of gender in which male and female were bound up with the polarities of culture and nature, activity and passivity, reason and emotion. ${ }^{33}$ All this implies that the "theoretical" part of midwifery dealing with "natural" childbirth basically concerned the type of cases which medical doctors were willing to leave to female midwives, while the "practical" part treated those complicated cases where male physicians or surgeons thought that their own intervention was required. ${ }^{34}$

There were, however, further reasons why Osiander called his course practical as well as theoretical. He held "practical exercises", in addition to the lecture course. Students appear to have been even more keenly interested in the former than in the latter. In the summer of 1796 , the only semester for which a list for both the "collegium theoreticum" and the "practical exercises" is preserved, 36 students participated in the lectures, but 49 in the practical part. All those who took Osiander's course for the first time, attended both; those who were repeaters participated in the practical exercises only. ${ }^{35}$ Not surprisingly, Osiander advertised this aspect of his course by emphasizing the demonstrations and exercises with a manikin or "phantom", a female pelvis covered by leather. Compared to mere lectures and even to pictures, this form of practise was considered to be a major improvement, and it was an important element in the courses taught by "the King's midwife", Madame du Coudray, to midwives, surgeons and physicians in many parts of France from 1759 to 1783 , as well as in the lessons given by William Smellie and other British menmidwives to male students since mid-century. ${ }^{36}$ Like his teacher Stein, ${ }^{37}$ Osiander was well aware of this practical turn in obstetric teaching, and during his first term in Göttingen he bought, at the hospital's expense, a phantom designed by a colleague in Jena. ${ }^{38}$ The next semester, he lectured on Mondays, Tuesdays, Thursdays and Fridays from 9 a.m. to 10 a.m., and set aside Wednesdays and Saturdays for practising with the dummy. Later he used the

\footnotetext{
${ }^{33}$ Schlumbohm, 'Pregnant women', op. cit., note 5 above, pp. 69-70.

${ }^{34}$ See Broman, op. cit., note 4 above, p. 29 , on medical education at eighteenth-century universities: "The division between 'theoretical' and 'practical' courses refers to the type of knowledge presented, not to the method of instruction."

${ }^{35}$ Archivmaterialien aus dem Bestand der Universitäts-Frauenklinik Göttingen, in der Bibliothek der Abteilung Ethik und Geschichte der Medizin der Universität Göttingen (hereafter AUFK Gö), W 29, fols 27-28. This was in line with Osiander's view that instruction by the oral and written word has to precede the practical training of accoucheurs; Osiander, Grundriss, op. cit., note 29 above, vol. 1, p. 11.

Repeaters paid only half the tuition fee of beginners, see note 99 below and related text.

${ }^{36}$ Jacques Gélis, La sage-femme ou le médecin: une nouvelle conception de la vie, Paris, Fayard, 1988, pp. 111-72, esp. 160-1, and photo between pp. 248-9; Nina R Gelbart, The king's midwife: a history and mystery of Madame du Coudray, Berkeley, University of California Press, 1998, pp. 60-4, 207, 213-14; Eva Labouvie, Beistand in Kindsnöten: Hebammen und weibliche Kultur auf dem Land, 1550-1910, Frankfurt/
}

Main, Campus, 1999, pp. 234-46; Laurence Brockliss and Colin Jones, The medical world of early modern France, Oxford, Clarendon Press, 1997, pp. 740-3; Matthew Ramsey, Professional and popular medicine in France, 1770-1830: the social world of medical practice, Cambridge University Press, 1988, pp. 24, 53; Adrian Wilson, The making of man-midwifery: childbirth in England 1660-1770, London, UCL Press, 1995, pp. 124-26; Johanna Geyer-Kordesch and Fiona Macdonald, Physicians and surgeons in Glasgow: the history of the Royal College of Physicians and Surgeons of Glasgow 1599-1858, London, Hambledon, 1999, pp. 261-4; Lisa Forman Cody, Birthing the nation: sex, science, and the conception of eighteenth-century Britons, Oxford University Press, 2005, pp. 171-2. Madame du Coudray, however, used a "machine" made out of textiles.

${ }^{37}$ Stein, Theoretische Anleitung, op. cit., note 26 above, 'Vorbericht', unpaginated.

${ }^{38}$ Osiander, draft of report to the government on the last quarter of 1792, 8-12 Jan. 1793, in AUFK Gö, O 4, pp. 28-9. In 1799, Osiander bought a second phantom, at his own expense, in order to give the students more opportunities for practising, UnivA Gö, Kur. 4731, fol. 37 . 


\section{The Practice of Practical Education}

entire final month of each semester for exercises with the phantom. ${ }^{39}$ He insisted that no more than four students per hour could practice on it. Therefore, in addition to the lessons which Osiander taught himself, he let groups of students exercise on their own, supervised by one who was more experienced than the rest. Even so, the time available for each student was quite limited. This is made plain in an announcement, handwritten by Osiander in late August 1793, and posted in the hospital at the end of his lecture course. He notified his students that the exercises with the phantom would continue during the first half of September, four days a week from 9.00 to 10.00 in the morning. He distributed the 31 students who remained out of the 36 who had attended his classes during the summer term into groups of four and assigned a day to each group. ${ }^{40}$ This meant that each student had just fifteen minutes' practice during the two-week period.

With the phantom, Osiander taught two things: first, the semiotics of foetal positions, i.e. how to discover the position of the unborn in the uterus by touching it with one or several fingers through the vagina, and, second, how to intervene in difficult cases. In particular, he demonstrated, and let his students practise, how to deliver a child presenting the feet, to turn a child in the uterus, and to use the forceps and the vectis. ${ }^{41}$ According to his peculiar approach, he refused to teach embryotomy, and insisted that, in almost all cases, a living child could be delivered with the forceps. ${ }^{42}$ Following Stein, Osiander endeavoured to make the exercise on the phantom as realistic as possible. They both preferred to use corpses of stillborn babies, preserved in alcohol, rather than artificial dolls. Osiander considered this to be the only effective way of training palpation, ${ }^{43}$ and there was always a supply of dead babies in the hospital.

Above all, the hospital made living patients available for teaching purposes. The students were thus trained in palpation not only on the phantom, but also on the pregnant women in the clinic. They learnt how to perform both external and internal manual examinations, and in this way determine the state of the pregnancy and the position of the foetus. A man touching a woman's genitals and womb clearly transgressed a strong shame taboo, and that was not easily allowed in private practise. ${ }^{44}$ The women in the hospital, however, who were mostly unmarried servants, ${ }^{45}$ had free board, lodging and treatment during their stay, and had to accept being used for this purpose. To be sure, midwives had practised manual examinations of pregnant women for a long time. For male obstetricians, however, it was a recent development, crucial for their efforts to build a knowledge of their own, independent of that of the women concerned. ${ }^{46}$ For this reason,

${ }^{39}$ GGA, 1793, no. 43, 16 March 1793, p. 431; Osiander, Denkwürdigkeiten, op. cit., note 21 above, vol. 1, part 1, pp. CVI-CVIII.

${ }^{40}$ AUFK Gö, W 29, fol. 14, cf. fols 8-9.

${ }^{41} \mathrm{~A}$ vectis is a lever used to free the child's head.

${ }^{42}$ Jürgen Schlumbohm, " "Die edelste und nützlichste unter den Wissenschaften”: Praxis der Geburtshilfe als Grundlegung der Wissenschaft, ca. 1750-1820', in Hans Erich Bödeker, Peter H Reill and Jürgen Schlumbohm (eds.), Wissenschaft als kulturelle Praxis, 1750-1900, Göttingen, Vandenhoeck \& Ruprecht, 1999, pp. 275-97, esp. 289-95.

${ }^{43}$ Osiander, Denkwürdigkeiten, op. cit., note 21 above, vol. 1, part 1, pp. CVII-CIX.

\footnotetext{
${ }^{44}$ Seidel, op. cit., note 18 above, pp. 286-91.

${ }^{45}$ Jürgen Schlumbohm, “ "Verheiratete und Unverheiratete, Inländerin und Ausländerin, Christin und Jüdin, Weiße und Negerin": die Patientinnen des Entbindungshospitals der Universität Göttingen um 1800', in H-J Gerhard (ed.), Struktur und Dimension: Festschrift für Karl Heinrich Kaufhold, 2 vols, Stuttgart, Steiner, 1997, vol. 1, pp. 324-43, on pp. 330-1.

${ }^{46}$ Idem, 'Grenzen des Wissens: Verhandlungen zwischen Arzt und Schwangeren im Entbindungshospital der Universität Göttingen um 1800', in Barbara Duden, Jürgen Schlumbohm and Patrice Veit (eds), Geschichte des Ungeborenen: zur Erfahrungs- und
} 


\section{Jürgen Schlumbohm}

teaching medical students how to examine pregnant women "according to the rules of the art" was an important part of the practical course. ${ }^{47}$

Like that of the medical students, the training of female midwives was theoretical as well as practical, although with significant differences in the content of the theoretical knowledge taught and in what was exercised on the phantom. Thus, in an announcement of the courses for the summer semester of 1796, posted in the maternity hospital, Osiander spoke of the "Collegium theoreticum" on the "science of obstetrics" for the male students, as opposed to the "lessons in the art of midwifery" for the female apprentices. ${ }^{48}$ The medical students were supposed to know Latin. As for the midwife apprentices, Osiander would have liked them all to be able to read and even write, but he was unable to insist on this because he had no control over which women came to his course. ${ }^{49}$ They were either elected by the married women in their community, or picked by local officers. ${ }^{50}$ In fact, many of them did not even speak high German, but only low German, the language of the North, including the Electorate of Hanover. During his first years in Göttingen, this appears to have been a problem for Osiander, since he was from Württemberg, in the southwest.

Like the lectures for medical students, the lessons for midwife apprentices were based on a textbook by Georg Wilhelm Stein, the Hebammen-Catechismus (Catechism for Midwives). Consisting of only about 100 pages, this was more elementary and shorter than the students' textbook, and was written in the form of questions and answers, which Enlightenment authors thought especially appropriate for teaching ordinary people. ${ }^{51}$ Osiander would ask the most literate apprentice to read out a paragraph from the textbook. He would then question the women to ascertain whether all had properly understood the meaning, and he endeavoured to imprint the matter firmly in their memory by using terms from their

Wissenschaftsgeschichte der Schwangerschaft, 17.-20. Jahrhundert, Göttingen, Vandenhoeck \& Ruprecht, 2002, pp. 129-65, on pp. 132-3; see also Anne Carol, 'L'examen gynécologique en France, XVIIIe-XIXe siècles: techniques et usages', in Patrice Bourdelais and Olivier Faure (eds), Les nouvelles pratiques de santé: acteurs, objets, logiques sociales (XVIIIe-XXe siècles), Paris, Belin, 2005, pp. 51-66.

${ }^{47}$ Osiander, Annalen, op. cit., note 7 above, vol. 1, part 1, 1800, p. X: “[Es wird regelmäßig] in dem kunstmäßigen Untersuchen an Schwangeren des Hauses Unterricht erteilt".

${ }^{48}$ AUFK Gö, W 29, fols 27-28: "In dem Collegio theoretico der Entbind[ungs]wissensch[aft] ..."; "Unterricht in der Hebammenkunst".

${ }^{49}$ Friedrich Benjamin Osiander, Lehrbuch der Hebammenkunst: sowohl zum Unterricht angehender Hebammen als zum Lesebuch für jede Mutter, Göttingen, Rosenbusch, 1796, p. 22, see also p. VI; idem, Denkwürdigkeiten, op. cit., note 21 above, vol. 1 , part 1, pp. CXVI-CXVII. In a list of five midwife apprentices who took his course in winter 1796/97, Osiander was happy to note that four of them, aged between thirty-one and forty-three, knew how to read and write; the fifth, aged thirty, could read, but not write; AUFK Gö, A 1 (Tagebuch, vol. 4), fols 362-3.
${ }^{50}$ Hampe, op. cit., note 22 above, pp. 45-59; see also Labouvie, op. cit., note 36 above, pp. 99-125; Seidel, op. cit., note 18 above, pp. 243-5.

${ }^{51}$ Osiander, Denkwürdigkeiten, op. cit., note 21 above, vol. 1, part 1, pp. CXV-CXVI. Georg Wilhelm Stein, Hebammen-Catechismus: zum Gebrauch der Hebammen in der Grafschaft Lippe, Lemgo, Meyer, 1776. In addition, he used Heinrich Georg Marschall, Unterricht zur Pflege der Mädchen und Schwangern besonders der Mütter, für sich und ihre Säuglinge, in ihren besondern Krankheiten und Zufällen: ein Volksbuch allen Hebammen und guten Müttern sehr nützlich, und nothwendig, Frankfurt/Main and Leipzig, 1791. In 1796, Osiander himself published a textbook for midwives, and used it in his courses: Osiander, Lehrbuch der Hebammenkunst, op. cit., note 49 above, p. XV. It contained more than 770 pages, however, not much fewer than his later text for medical students (Osiander, Grundriss, op. cit., note 29 above), and he admitted that it was not written for normal courses and ordinary midwives, but rather for the educated few among them, and for teachers of midwives. It was to be "a bible of their art" ("eine Bibel ihrer Kunst"), all the knowledge in a single volume. Moreover, the book was destined for a broader public of enlightened laypersons, namely "noble and middle class ladies", civil servants 


\section{The Practice of Practical Education}

dialect, giving examples, and showing drawings, copper engravings and preparations from his collections. ${ }^{52}$

The professor insisted that the "midwives" art" is to the "science of obstetrics" as a part is to the whole. This is evident in the way "contranatural" deliveries were treated. Whereas in the textbook for medical students most of the second volume was devoted to this topic, in the reader for midwives only one chapter out of sixteen dealt with such deliveries, and the information given was strictly limited to what a midwife was required know about the subject. ${ }^{53}$ On the other hand, the latter book had a chapter on the female body in general, in addition to one on female genitals, several chapters on how to treat newborn babies and women after birth, including common diseases of both, and a section on religious customs in different religions, Protestant and Catholic baptism as well as Jewish circumcision. All this was missing in the text for medical students. Also in terms of practical skills, the apprentices were taught to administer clysters, insert catheters, perform phlebotomies and put on bandages,${ }^{54}$ and they were trained in nursing. At least part of this was probably taught by the hospital midwife, who was in charge of these tasks in the wards. ${ }^{55}$

With the dummy, the female apprentices were shown, and practised, how to determine the position of the foetus, and to deliver a child presenting by the feet or the breech. For emergencies, they were even supposed to learn how to turn a foetus in the uterus. ${ }^{56}$ They were taught to do these operations manually, ${ }^{57}$ but never how to use instruments. The forceps, in particular, were for Osiander, as for most obstetricians, the exclusive privilege of male accoucheurs. ${ }^{58}$ In the physical examination of patients, midwives learnt the same skills as male students.

and clergymen, who felt responsible for the health of the people, in particular for the lives of women and babies; Lehrbuch der Hebammenkunst, pp. V-VII, XII-XV.

${ }^{52}$ Ibid., p. XV. Of course, Osiander used his collections for the students' lecture course as well; GGA, 1803, no. 50, 26 March 1803, p. 496.

${ }^{53}$ Osiander, Lehrbuch der Hebammenkunst, op. cit., note 49 above, p. 8: "Die Hebammenkunst unterscheidet sich von der Entbindungswissenschaft ... wie ein Teil vom Ganzen"; pp. 398-460: "Von den widernatürlichen Geburtsfällen, in so weit sie einer Hebamme zu wissen nötig sind ...".

${ }^{54}$ Osiander made no mention of teaching these skills to medical students, but at least those who studied surgery, and not only physics, must have learnt them somewhere. Osiander reported that, in his early days in Göttingen, when there was not as yet a hospital midwife, he did most of the surgical tasks himself or had them done by those students who attended his course for free; Osiander, draft of report to the govern-

ment on the last quarter of 1792, 8-12 Jan. 1793, in AUFK Gö, O 4, p. 25. Later, he offered to take any student who was eager to learn to the beds of pregnant patients, infants and sick lying-in women; AUFK Gö, W 29, fols 25-26, section 16 . In the general polyclinic, directed by Osiander 1792-1802, students could learn and practise surgical skills; Renate Kumsteller, Die Anfänge der medizinischen Poliklinik zu Göttingen,
Göttingen, Häntzschel, 1958, pp. 32-4; Bueltzingsloewen, op. cit., note 6 above, pp. 242-50.

${ }^{55}$ Osiander, Denkwürdigkeiten, op. cit., note 21 above, vol. 1, part 1, pp. LXXXVIII-LXXXIX, CXVI.

${ }^{56}$ Ibid., p. CXVI; idem, Lehrbuch der

Hebammenkunst, op. cit., note 49 above, p. XI, see also pp. 441-50. Osiander thought this necessary because a doctor could often take too long to arrive. What midwives were taught and allowed to do in difficult deliveries, tended to be defined more narrowly, in the course of the nineteenth century, with the growing numbers of doctors; Seidel, op. cit., note 18 above, pp. 256-9.

${ }^{57}$ Osiander, Annalen, op. cit., note 7 above, vol. 1, part 1, 1800, p. XI: “. . . die Hebammen [werden] auch im geschickten Entbinden mit den Händen am Fantome unterrichtet ...".

${ }^{58}$ Seidel, op. cit., note 18 above, pp. 257-8. In the lying-in hospital of Port-Royal, Paris, the chief midwife, who in fact ran the hospital, did use the forceps, although otherwise it was forbidden to midwives; Scarlett Beauvalet-Boutouyrie, Naître à l'hôpital au XIXe siècle, Paris, Belin, 1999, pp. 128, 158-61, 178. In thinly populated Sweden, midwives were allowed to use instruments, including forceps; Christina Romlid, 'Swedish midwives and their instruments in the eighteenth and nineteenth centuries', in Hilary Marland and Anne Marie Rafferty (eds), Midwives, society and childbirth: debates and 


\section{Jürgen Schlumbohm}

Osiander appears to have felt uneasy about male and female pupils being present in the same building at the same time. ${ }^{59}$ Once, on the day that he started the course for midwives, he posted a handwritten message to the medical students, explaining changes in the schedule for practices with the phantom and examinations of patients. At the end he admonished the young men: "I have already told these women [i.e. the apprentices] to behave in the most decent and polite way towards you, gentlemen. I also hope that you, thanks to your good manners, will behave most decently towards them." ${ }^{60}$ In many ways, the professor drew as clear a line as possible between the "gentlemen"-students and the "women"-midwives. Whereas he spoke directly to the apprentices, he addressed the disciples in writing, often sending them messages in Latin, for example, invitations to attend a post mortem or the circumcision of a newborn Jewish boy. Even the "order and statutes" of the hospital, in so far as they concerned the "most noble and honourable students of the healing art", were composed in Latin by Osiander. ${ }^{61}$ The courses for both groups took place in the same building, probably in the same room, the "teaching hall" (Lehr-Saal), but at different times. In the summer of 1796, the lecture course on "the science of obstetrics" was scheduled on Mondays to Fridays from 9 a.m. to 10 a.m., and the "lessons in the art of midwifery" from 10 a.m. to 11 a.m. on the same days. ${ }^{62}$ In 1800 , he taught the midwives' class from 11.00 to $12.00,{ }^{63}$ possibly in order to avoid contact between the two groups. The exercises in examining patients were on different days for the two sexes, in some years on Wednesdays for male students, and on Saturdays for female apprentices. ${ }^{64}$

When it came to using patients as teaching material, it is evident that the two groups competed with each other for a relatively scarce resource. In the summer semester, there were always fewer women in the hospital than in the winter, since, being single, many of them simply required shelter during the difficult period before and after childbirth. ${ }^{65}$ In spring 1793, the hospital housed on average only two or three pregnant patients at a time. ${ }^{66}$ Therefore, on 12 June 1793, Osiander felt obliged to write a long letter to the gentlemen, his students, in order to resolve "a misunderstanding that seems to prevail regarding the examination of the pregnant women". He stated that the frequency with which each student could practise physical examinations depended, first, on the number of pregnant patients in the hospital, and, second, on the number of "gentlemen" and "midwives" using the

controversies in the modern period, London, Routledge, 1997, pp. 38-60.

${ }^{59}$ At Port-Royal, Paris, the chief midwife argued that male and female pupils could not be taught together, and in this way kept medical students out of the maternity hospital,

Beauvalet-Boutouyrie, op. cit., note 58 above, pp. 108-9. In Vienna, however, male students and female midwives were taught together in the theoretical lessons until 1833; Fischer, op. cit., note 18 above, p. 256.

${ }^{60}$ AUFK Gö, W 29, fol. 3, undated, probably from the 1790s: "Ich habe diesen Frauen schon gesagt, dass sie sich gegen Sie, m[eine] H[erren], auf das Bescheidenste $\mathrm{u}[\mathrm{nd}]$ Höflichste betragen sollten; ich hoffe es auch von Ihren guten Sitten, dass Sie sich aufs
Wohlanständigste gegen dieselbe[n] betragen werden."

${ }^{61}$ AUFK Gö, W 29, fols 5, 12, 25-6, 29.

${ }^{62}$ See note 48 above.

${ }^{63}$ Osiander, Annalen, op. cit., note 7 above, vol. 1, part 1, 1800, p. XI.

${ }^{64}$ AUFK Gö, W 29, fol. 3.

${ }^{65}$ Schlumbohm, 'Verheiratete und Unverheiratete', op. cit., note 45 above, pp. 338-9.

${ }^{66}$ In April 1793, the average number of pregnant patients staying in the hospital at the same time was 2.6, in May 1.9, in June 3.3. For the whole period 17911799, the average was 7.0. The total number of patients (pregnant and lying-in) staying in the hospital at the same time averaged 6.8 in April 1793, and 4.2 in May and June 1793, compared to 10.1 for 1791-1799. 


\section{The Practice of Practical Education}

teaching institution. He explained at length that "a pregnant woman cannot be expected to let herself be examined more than twice a week", each time by no more than three, or at most four persons. More frequent examinations would not be "advantageous" either to her or her "fruit", or to the attendance of the hospital. Most patients abhorred being examined, and there were even rumours that the relatively numerous contranatural deliveries in the clinic were caused by the many physical examinations - which was not, of course, the case. For this reason, Osiander divided his students into two groups and gave each of them a number. Those in the first group would examine the pregnant women on Wednesdays, those in the second, on Saturdays. Each week, however, only three from each class would be allowed to examine, in the order of their numbers, and each day only half of the patients would be there for them. The other half would be examined by the midwife apprentices. In this way, each of the 36 medical students present in the 1793 summer semester (Table 1, col. 3) had an equal chance to practise physical examination of the pregnant women. But while there were so few patients, only six per week were allowed to do this, and it took six weeks before all had had their turn. As a consolation, Osiander stressed that, as soon as the midwives' course finished at the end of July, more women would be available for the medical students. ${ }^{67}$

In his letter to the "gentlemen", the professor did not conceal the fact that only two midwives participated in the summer 1793 course. What seems to be a fair compromise between the categories of medical students on the one hand, and apprentices on the other, amounted to a very uneven distribution of opportunities for examining pregnant women, if calculated per person. The two midwife apprentices would have weekly, or even twice weekly, practices, whereas for each medical student the opportunity arose only once in six weeks. To be sure, the apprentices stayed for only three months, and the students could use the time between the semesters and courses. Nevertheless, the majority of students, that is those who took the course in obstetrics just once, probably examined real women in the hospital only twice or at most four times during the whole of their training at Göttingen.

It appears that for practice on the phantom there was also equality between medical students and midwives, considered as groups. Due to the much greater number of students, however, each of them had far fewer opportunities to exercise with the dummy. As for the theoretical part of the course, the number of hours taught was equal for both categories. Although the midwives' class was much smaller, so that they could easily ask, or be asked, questions, Osiander made it clear that he could teach much less to the women, who were not accustomed to learning in the classroom. "It is easy, says the proverb, to preach to learned persons, but converting pagans demands the talents of an apostle." 68

Calculated with my database, from the admission records: AUFK Gö, C 1-2.

${ }^{67}$ AUFK Gö, W 29, fols 10-11: "Da in Absicht des Untersuchens der Schwangeren ein Missverständnis vorzuwalten scheint, so muss ich Ihnen folgende

Erläuterung geben. ... Einer Schwangeren kann man nicht zumuten, dass sie sich wöchentlich mehr als 2 mal untersuchen lasse. Auch würde es weder ihr selbst und ihrer Frucht noch der Frequenz des Instituts vorteilhaft sein, wenn es allzu oft vorgenommen würde ...". The list with the names of the 36 students of the summer semester 1793, numbered and divided into two classes, survives, fols $8-9$.

${ }^{68}$ Osiander, Lehrbuch der Hebammenkunst, op. cit., note 49 above, p. V: "Den Gelehrten, sagt das Sprüchwort, ist gut predigen, aber das Heidenbekehren erfordert apostolische Gaben." 


\section{Jürgen Schlumbohm}

The midwives' course, which lasted for three months, as in many other German places during this period, ${ }^{69}$ was obviously short by comparison with the course of one or even two years for the elite of French midwives in the big maternity hospital of Port-Royal, Paris. ${ }^{70}$ Nevertheless, compared with the great majority of Göttingen medical students, who studied obstetrics for only one or two semesters, the female apprentices had much better opportunities to acquire practical skills. This is true not only in terms of the minor everyday chores which, living in the house day and night, they shared with the hospital midwife as a matter of course, but also of exercises on the phantom and examinations of real women. This is a rather surprising finding, since Osiander never ceased to emphasize that his maternity hospital was a university institution, and that its foremost goal was to educate skilful doctors as men-midwives.

What about the most crucial occasion the hospital could offer for practising midwifery, attending childbirth?

\section{"To Derive as much Benefit for Teaching as Possible from the Births"}

Professor Osiander was proud of his unfailing presence in the clinic: "At every delivery, whether in the day or at night, I am present from beginning to end, unless prevented by illness, a visit to a village or other urgent business." 71 The birth protocols in the medical diaries, handwritten by the director, confirm this. ${ }^{72}$ Implicitly, Osiander compared his institution with the huge maternity hospitals, such as those in Vienna or Paris, which had more than a thousand births per year, most of which were, however, attended by midwives and midwife apprentices, not the medical director. ${ }^{73}$ " [T] hroughout, it is my intention to derive as much benefit for teaching as possible from the births which occur here. If one does this, one hundred births can be more instructive than thousands in another lying-in hospital."74

\footnotetext{
${ }^{69}$ During the first half of the nineteenth century, courses for midwives usually lasted between three and six months in Germany, Seidel, op. cit. note 18 above, pp. $260-1$.

${ }^{70}$ In the 1790 s, the course at Port-Royal lasted for six months, but in 1807 it was extended to one year. From $c .1815$, however, about one-third of the pupils stayed for two years, encouraged by the school,

Beauvalet-Boutouyrie, op. cit., note 58 above, pp. 108, $113,119,137,188$. In the French provinces, courses usually lasted between 6 months and a year in the beginning of the nineteenth century; ibid., pp. 210,379; see also Labouvie, op. cit., note 36 above, pp. 264-78.

${ }^{71}$ Osiander, Annalen, op. cit., note 7 above, vol. 1, part 1, p. XIV: "Bei jeder Geburt, sie sei bei Tag oder bei Nacht, bin ich, wenn keine Krankheit, Reise aufs Land oder ein anderes wichtiges Geschäft mich hindert, vom Anfange bis zu Ende zugegen ...".

${ }^{72}$ I have used systematically, i.e. by means of a database, Tagebücher, vol. 4 (1795-97), 6-7 (1799-1802), 10-14 (1806-14): AUFK Gö, A 1-8. Apparently, vols. 1-3, 5, 8-9 have not survived. Where no other source is cited, this database and/or that of the
}

chronological lists of deliveries in the calendars (see below note 89) has been used.

${ }^{73}$ Beauvalet-Boutouyrie, op. cit., note 58 above, pp. 124-34, 226-30; Fischer, op. cit., note 18 above, pp. 174, 194-5, 200-1, 255, 485-7; see also Verena Pawlowsky, Mutter ledig-Vater Staat: Das Gebär-und Findelhaus in Wien 1784-1910, Innsbruck,

Studienverlag, 2001, pp. 289-92, 297-9. In the

Rotunda Hospital of Dublin, too, most births appear to have been attended by female midwives, at least in the early period; Ian Campbell Ross (ed.), Public virtue, public love: the early years of the Dublin lying-in hospital, the Rotunda, Dublin, O'Brien Press, 1986, pp. 152, 159-63; Alan Browne (ed.), Masters, midwives and ladies-in-waiting: the Rotunda Hospital 17451995, Dublin, Farmar, 1995, pp. 66-69, 76-81. Even in the maternity hospital of Kassel, which had about 100 births per year in the 1770 s, the director Stein delivered only 7 per cent of the patients, whereas 83 per cent were attended by midwives; Vanja, op. cit., note 25 above, pp. 111, 114-15.

${ }^{74}$ Osiander, Denkwürdigkeiten, op. cit., note 21 above, vol. 1, part 1, pp. CX-CXI: “... überhaupt ist mein Absehen beständig dahin gerichtet, aus den 


\section{The Practice of Practical Education}

In his publications, Osiander described how he organized this core of practical teaching. When a woman had gone into labour and her orificium uteri was open four fingers wide, the students, whose lodgings were scattered through the town, were called in by the hospital's servant. Then the parturient woman was led from her bed to the delivery room and placed on the birth stool. The students assembled in the adjacent room, as did the apprentice midwives, who lived in the hospital during their course. Osiander called some of the advanced students into the delivery room and had them examine the woman. They reported their findings on the position of the child and the state of the birthing process. Then, the professor explained the situation to the whole audience in the adjacent room. Using the dummy and an artificial head of a baby, he showed the position of the child, pointed out any impediments to the birth and indications for intervention, and demonstrated the course of action he had chosen. He strove to make the logical sequence from diagnosis to action and success as transparent to the learners in the delivery room as it appeared in his handwritten and published case histories. ${ }^{75}$ If Osiander had decided to "leave the birth to nature", he asked one of the apprentice midwives to assist. If he opted for "artificial" help, he called upon one of the advanced students. Now the entire audience entered the delivery room. They found the upper half of the parturient's body hidden by a green curtain, so that "her shame was spared, as much as the circumstances allow". "Up to her genitals", she was naked "so that all the audience could observe the procedure". The hospital's midwife stood at her side and "instructed her how to push skilfully during contractions". The professor sat next to the student or apprentice whom he had invited to attend. He directed the "business", and took over himself as soon as the attendant experienced difficulties or made an error. ${ }^{76}$

As this description makes clear, there were several levels at which pupils participated in the deliveries: watching, examining, helping in a natural birth, assisting in an artificial delivery. The higher the level, the fewer the number of those who had access to it.

From his second semester in Göttingen, Osiander divided his students into two groups, at least when there were more than thirty, so that only half of them were present at each birth, except in especially complicated cases, when all were summoned. ${ }^{77}$ The students appear to have kept a careful eye on getting their fair chance of observing deliveries. In December

vorfallenden Geburten so viel möglich Nutzen für den Unterricht zu ziehen. Tut man das, so können hundert Geburten lehrreicher sein als auf einem andern Gebärhause tausende."

${ }^{75}$ Jürgen Schlumbohm, 'Der Blick des Arztes, oder: wie Gebärende zu Patientinnen wurden. Das Entbindungshospital der Universität Göttingen um 1800 ', in J Schlumbohm, B Duden, J Gélis, P Veit (eds), Rituale der Geburt. Eine Kulturgeschichte, Munich, Beck, 1998, pp. 170-91, on pp. 181-2.

${ }^{76}$ Osiander, Annalen, op. cit., note 7 above, vol. 1, part 1, 1800, pp. XII-XV: "Wird die Geburt der Natur überlassen ...; soll sie künstlich beendigt werden ...;" "... damit ihre Schamhaftigkeit, so viel es wenigstens die Umstände erlauben, geschont wird”; “. . . wird die Gebärende bis an die Geburtsteile entblößt, damit alle Zuschauer den Hergang ... sehen können"; "die
Hospital-Hebamme [weist die Gebärende] zum geschickten Verarbeiten der Wehen an; [ich] leite das Geschäft". See also Schlumbohm, 'Pregnant women', op. cit., note 5 above, pp. 68-9.

${ }^{77}$ AUFK Gö, W 29, fols 8-9; Osiander, Annalen, op. cit., note 7 above, vol. 1, part 1, 1800, pp. XI-XII. AUFK Gö, W 29, fols 16-17, 23, show that even in the winter semesters 1793/94 and 1794/95 when there were only 24 or 27 students, Osiander divided them into two classes. In the Latin "order and statutes" of the hospital, from around 1795, he announced that, if there were more than 15 students, they would be divided into two classes, and if there were more than 30 , into three. However, he added later, "If the number is not too big, only two classes"; AUFK Gö, W 29, fols 25-26, section 7. The lists of Osiander's students, preserved for the summer semester 1795 , the winter semester $1795 / 96$ 


\section{Jürgen Schlumbohm}

1797, the professor received an anonymous letter complaining that in some cases not all the students had been called when births took place. Taking this charge seriously, he replied in an open letter that, in spite of all his efforts, it was inevitable that sometimes a delivery came to a natural end, or had to be terminated for urgent reasons, before all the gentlemen whom he had summoned arrived. He reminded his students that his ultimate aim was to make all of them, without any exception, profit from the deliveries in the hospital. He explained that, precisely for this reason, he had tried, in the current semester, to have all the students called to each birth, instead of just half or even a third of them. But since some, who did not know what they could reasonably demand, were dissatisfied, he found it necessary to return to the former order, dividing the students into two classes, which would be summoned to deliveries alternately. ${ }^{78}$ It is evident that, even in a relatively small town like Göttingen, ${ }^{79}$ it took a considerable time for the hospital's servant to call at all the different houses where the students (41 in the winter of 1797/98) lived. On the other hand, this may have made it easier for Osiander to manipulate the order and eventually to exclude some students if there were too many. For the midwife apprentices, Osiander did not deem it necessary to divide them into two classes, because there were usually only between two and six, so all could watch every delivery.

While some births progressed too quickly, many lasted for long hours, even after the students had arrived at the hospital. In such a case, they tended to enter the delivery room early in order to get the best places in front of the parturient woman. The professor told the students repeatedly to wait in the hall until the last phase of labour, when he called them in. Not only would it be useless for them to stand for hours in the small "cell", but their gazing at the patient for a long time and talking to each other would frighten and torment her. Moreover, it could disturb Osiander while he wrote the birth protocol into the hospital diary, although in principle he loved having useful conversations with his students while the patient was in labour. ${ }^{80} \mathrm{He}$ appealed to their good manners: "Honourable and diligent students will on their own initiative refrain from smoking tobacco in this building, passing the time by playing cards, causing quarrels or tumults, bringing dogs, and entering the rooms of pregnant women." ${ }^{81}$ As a positive alternative, in December 1794 he started to build up a collection of obstetric books to be stored in the hall next to the delivery room, where they could be read by his keen students during the hours of waiting. ${ }^{82}$

and the summer semester 1796, show that he always had two groups, for a total of 30, 40, 49 students respectively, ibid., fols 24, 27-8; AUFK Gö, A 1 (Tagebuch, vol. 4), fols 364-5.

${ }^{78}$ AUFK Gö, W 29, fol. 31. The draft, dated 5 Dec. 1797 , is also preserved, ibid., fol. 30 . The list of his students in the winter semester 1797/98, handwritten by Osiander in the hospital's copy of Cellescher ArzeneyKalender auf das Jahr 1798, Lauenburg, Berenberg, [c.1797], is divided into two classes of 22 and 19: AUFK Gö, I 3. Normally both classes were of equal size, or differed only by one.

${ }^{79}$ Göttingen had about 10,000 inhabitants in this period; Wieland Sachse, Göttingen im 18. und 19. Jahrhundert: zur Bevölkerungs- und Sozialstruktur einer deutschen Universitätsstadt, Göttingen, Vandenhoeck \& Ruprecht, 1987, pp. 85, 256-9.
${ }^{80}$ AUFK Gö, W 29, fols 25-26, section 10, and fol. 30; cf. Osiander, Annalen, op. cit., note 7 above, vol. 1, part 1, 1800, p. XV.

${ }^{81}$ AUFK Gö, W 29, fols 25-26, section 15: “Ab hauriendo tabaci fumum in hac aede, a transigendo tempus chartis lusoriis, a ciendo rixas et tumultus, $a b$ adducendo canes, ut et ab intrando cellas gravidarum honesti et diligentes studiosi sponte abstinebunt." The only game allowed was chess, fol. 20 .

${ }^{82}$ AUFK Gö, N 1 (F B Osiander, 'Catalogus Bibliothecae Medicae Instituti Regii Obstetricii in Alma Georgia Augusta'); see also AUFK Gö, W 29, fols 20-1. For this library, Osiander asked the students for voluntary subscriptions, and assured them that contributors would decide about further acquisitions by majority vote, though out of a list of titles he would prepare. As a start, he donated some of the books he had 


\section{The Practice of Practical Education}

With regard to the second level of participation, i.e. physical examinations during the birthing process, Osiander makes no explicit mention of apprentices being invited to do these, but does speak of students in this context, even "several" at a time. ${ }^{83}$ Presumably no more than three or four of them were admitted to a parturient woman, as in the case of pregnant patients, since examining a woman in labour involved the risks of untimely disruption of the amniotic sac or of causing a swelling on the head or other parts of the child. ${ }^{84}$ In any case, the professor ordered the students to enter the delivery room for the physical examination one by one. The reason he gave was not consideration for the woman, but that the subsequent gentleman should not hear the findings of the previous one. $^{85}$

Actually assisting or intervening in a delivery was the highlight of practical education, usually reserved for one student or apprentice per case, rarely to more than two. The scarcest and the most crucial of the opportunities which the hospital could offer was carefully regulated. "[T]he gentleman whose turn it is" was "always called first", and "is obliged to stay not only to the end of the birth, but until the delivered woman is led to her bed". Students were left in no doubt that this was an occasion not to be missed; they would have to wait a long time for another. "If the gentleman whose turn it is voluntarily transfers the delivery to somebody else, he is nevertheless considered to have attended it himself." ${ }^{86}$ By posting in the hospital the list of students, numbered and divided into classes, the professor allowed them, at least in principle, to check that such opportunities were distributed in an impartial way. On the list for the 1793 summer semester, which appears to have been put up after the "misunderstanding" of 12 June, he explicitly stated: "The gentlemen take care of the births in the order noted here." ${ }^{87}$ In his letter of 12 June, however, he had made a proviso in favour of the female apprentices: "from St John's day [24 June] to the end of July, the two midwives will alternate with the gentlemen in attending the births occurring in the hospital", or at least the "natural" ones. He assured the students: "Nevertheless, each time one of the gentlemen's groups will be summoned." 88

published, and promised to give one or several volumes every year. In the winter semester 1794/95, 14 out of his 27 students contributed between a sixth to a third of a taler each; in the summer 1795 semester, 11 (out of 30) gave a third of a taler each. With this money, 3 volumes of one of the earliest German obstetric periodicals were bought (Archiv für die Geburtshülfe, Frauenzimmerund neugebohrner Kinderkrankheiten und

Pharmakologie, ed. Johann Christ[ian] Stark, 6 vols, Jena, 1787-1797), and several donated books were bound. Originally, Osiander had planned to make the students' contributions to the library compulsory;

AUFK Gö, W 29, fols 25-26, section 3.

${ }^{83}$ Osiander, Annalen, op. cit., note 7 above, vol. 1, part 1, 1800, p. XII: “' “einige' von den 'Studierenden',"

${ }^{84}$ The former, about which Osiander was not particularly concerned, was frequently mentioned in the birth protocols, e.g., AUFK Gö, A 5 (Tagebuch, vol 11), no. 137 (1809); A 6 (Tagebuch, vol. 12), no. 16 (1810), 105 (1811). For the latter, see AUFK Gö, A 3
(Tagebuch, vol.7), no. 107 (1802). See also Osiander, Lehrbuch der Hebammenkunst, op. cit., note 49 above, p. 371; idem, Grundriss, op. cit., note 29 above, vol. 1, p. 293.

${ }^{85}$ AUFK Gö, W 29, fols 25-6, section 13.

${ }^{86}$ AUFK Gö, W 29, fols 8-9: "Derjenige Herr, an dem die Reihe ist, wird immer zuerst gerufen und ist schuldig, nicht nur bis zu Ende der Geburt, sondern bis die Entbundene ins Bett gebracht ist, bei der Entbundenen zu bleiben. Wird die Geburt von dem Herrn, an dem die Reihe ist, freiwillig einem andern übertragen, so wird jener doch angesehen, als ob er sie selbst besorgt hätte"; cf. fols 25-6, sections 9 and 11 .

${ }^{87}$ AUFK Gö, W 29, fols 8-9: "Die Geburten übernehmen die Herrn nach der hier verzeichneten Ordnung." On the back of this list, as on that of several others, there is sealing-wax on the four corners, which shows that it was posted.

${ }^{88}$ AUFK Gö, W 29, fol. 11: "Noch muss ich Ihnen bei dieser Gelegenheit anzeigen, dass von Johannis an bis Ende Julii die 2 Hebammen die vorfallende [the 


\section{Jürgen Schlumbohm}

Thus, Osiander, as hospital director, claimed to establish a just and transparent order, balancing the chances for practical experience, both between students and midwives as groups, and between individuals within each category, especially among students.

To what extent did he in practice observe the regime he had proclaimed? Since he used to note the name of the birth attendant in the diary, and in some years in the calendar where he briefly registered the deliveries, it is possible to examine this question. ${ }^{89}$ In several semesters, including the summer of 1793, he even tallied the list of students with the deliveries attended by the respective gentlemen. In April and May 1793, no midwife is recorded as birth attendant. Among the students, the deliveries were distributed very unevenly, which may have been an additional reason for the discontent or "misunderstanding" that Osiander tried to resolve by his letter of 12 June and by dividing the students into two classes. Out of the eleven births occurring between 1 April, which can be considered as the beginning of the summer semester, and 11 June, the day before Osiander's letter, Johann Dietrich Hensing from Kurland, one of the Baltic provinces of the Russian empire, took care of no less than three deliveries, on 3, 14 and 18 April. ${ }^{90}$ Dr Johann Ludwig Eberhard Orth from Heilbronn, a Free Imperial City in southwest Germany, attended two deliveries on 5 April and 1 June. ${ }^{91}$ Six other students were in charge of one birth each. ${ }^{92}$ Did things become more equal once the professor had announced a transparent order on 12 June? The next birth, on 16 June, was attended by Frau Spangenbergin, one of the two midwife apprentices, despite Osiander's having told his students that the women would not perform deliveries before St John's day. But the first student of the second class, Joseph Jacob Gumprecht, son of a Jewish family in Göttingen, assisted the same delivery, incidentally of twins. ${ }^{93}$ Contrary to what the professor had announced, the following birth, on 6 July, was also assisted by a midwife, Frau Gottgardin, although Osiander himself intervened as well. Then, two days later, it was a student's turn, but not the one next on the list. Instead it was Gumprecht again. The attendants in the next four cases matched the order set out in June: on 10 July, one of the gentlemen had his first

following word has been added later:] natürliche Geburten auf dem Hause abwechslend mit den Herrn verrichten werden. Es wird jedoch jedes Mal eine Classe der Herrn dazu gerufen werden."

${ }^{89}$ From Osiander's period, calendars survive for 1793, 1794, 1798: AUFK Gö, I 1-3. For the diaries (Tagebücher) see above note 72 .

${ }^{90}$ AUFK Gö, I 1 (Kalender 1793). J D Hensing had already attended a delivery in Feb. 1793, and carried out another in Aug. 1793. He was born in 1770, matriculated as a student in Göttingen on 11 Oct. 1790, later practised as a rural doctor in Kurland and published several volumes on pharmacy; Selle (ed.), op cit., note 16 above, no. 15696; August Hirsch (ed.), Biographisches Lexikon der hervorragenden Arzte aller Zeiten und Völker, 6 vols, Vienna, Urban, 1884-1888, vol. 3, p. 162.

${ }^{91}$ J L E Orth matriculated only on 20 April 1793, but had been a student in Würzburg before, where he probably took his MD degree; Selle (ed.), op. cit., note 16 above, no. 16652 . He attended no more births in Göttingen, and is crossed out in Osiander's list of students in summer 1793, which probably means that he left before the semester was finished. He appears to have stayed in Göttingen only for a couple of months, for a special training in midwifery.

${ }^{92}$ Sometimes, two birth attendants were mentioned, especially, but not exclusively, if Osiander was one of them. In other cases, Osiander noted that he took care of the delivery alone.

${ }^{93}$ Born in 1772, J J Gumprecht matriculated in Göttingen 12 Sept. 1787, took his doctoral degree in Dec. 1793, and became a lecturer (Privatdozent) at Göttingen University in the summer of 1800 . In Sept. 1800, however, a fierce quarrel with Osiander broke out, when Gumprecht attacked Osiander publicly, criticizing his excessive use of forceps and his way of teaching. Osiander responded angrily, openly mobilizing anti-Jewish stereotypes. See Selle (ed.), op. cit., note 16 above, no. 14692; Eberhard Wolff, 'Antijudaismus als Teil der Judenemanzipation: die Auseinandersetzung des Göttinger Geburtshelfers Friedrich Benjamin Osiander mit seinem Schüler 


\section{The Practice of Practical Education}

opportunity, and Frau Spangenbergin assisted once more; on 14 July another student was called upon; on 18 July Frau Gottgardin helped alone; and on 20 July, Osiander did a forceps operation, assisted by yet another student. Then, on 27 July, the last delivery of the month was performed by the professor alone.

At the end of their three-month course, therefore, each of the two midwife apprentices had attended two births. Out of the 36 students, however, during the six months of the summer semester (April-September), 20 had not been in charge of any delivery. Twelve had taken care of one birth each, three of two, and one (Hensing) of four births. The order in which the students attended the deliveries does not correspond at all to the numbers on Osiander's list. There was not even a regular alternation between the two classes of 18 students. From the first class, 11 students attended fifteen births, whereas from the second, 5 students took care of only seven births.

In the winter semester of 1793/94, there were, as usual, more births than in the summer, so the chances for gaining practical experience were better. Out of 27 students, only 8 were not in charge of any delivery. Thirteen attended one birth each, three took care of two, and one of three births. Two students, however, took care of six and eight deliveries respectively. One of them was Gumprecht, who took his MD degree in December. As in the summer of 1793, the order in which the students were called did not follow a consistent pattern, and there was a great imbalance between the two classes. From the first, 10 students attended twenty-six times, whereas from the second class, 6 gentlemen attended once each. ${ }^{94}$ Only one apprentice, Frau Heiderin, took part in the midwives course during the last quarter of 1793 (Table 1, col. 5). She was in charge of two births on 3 and 13 December. ${ }^{95}$

Why did Osiander deviate so far from the order which he himself had drawn up? In the Latin "order and statutes", which he composed in about 1795, he announced a major exception to a strictly numerical order of students attending deliveries: "In assisting in childbirth, priority is given to those students who have already attended my lecture course." 96 Does this proviso explain the deviations from the order in the lists? In some of these documents, the students who took the course for the second or even third time are marked. In fact, all those who attended more than two deliveries per semester were repeaters. ${ }^{97}$ On the other hand, 18 out of 45 repeaters, that is 40 per cent, were not allowed to take care of any births. It is clear from this that Osiander distributed such opportunities among his students much less fairly or systematically than he tried to make them believe.

Joseph Jacob Gumprecht um 1800', Medizin, Gesellschaft und Geschichte, 1998, 17: 57-100.

${ }^{94}$ There were two classes of 12 students, and 3 latecomers who were not distributed to one of the classes, nor reported in Osiander's statistics that are the source of Table 1, col. 3; AUFK Gö, W 29, fols 16-17.

${ }^{95}$ Another birth, on 20 Nov., was attended by the hospital midwife, Frau Pikin. Nominative lists of Osiander's students are not preserved for all semesters. For example, they are missing for winter 1792/93 and summer 1794. For other semesters, not all the births are recorded in the surviving Tagebücher or calendars. This is true for winter 1794/95 and summer 1795 .

${ }^{96}$ AUFK Gö, W 29, fols 25-26, section 8: "Ii vero auditores primum in partus auxilio exercendo locum tenent, qui collegium meum jamjam frequentarunt."

${ }^{97}$ In the semesters of summer 1793, winters 1793/ 94 and 1795/96, and summer 1796 (i.e. those for which we have all the relevant information), there were 7 students who were in charge of more than two births per semester, the maximum being eight births. 


\section{Jürgen Schlumbohm}

There may, however, be an explanation why some students had more opportunities than others for gaining practical experience with deliveries. In some of the lists of students (though not in those posted in the hospital) there was a separate section of those who took a "privatissimum" with Osiander. ${ }^{98}$ These were private lessons and exercises attended by very small groups or only one gentleman, for which the professor charged a high honorarium. To be sure, even Osiander's normal theoretical and practical course in midwifery was "private" and cost each student ten taler per semester, as was usual at Göttingen University in this period, and five taler for repeaters, although poor students were admitted free. ${ }^{99}$ The privatissima, however, were much more expensive and exclusive. They added a market element to the educational system of state universities in Germany. ${ }^{100}$ In most cases, such private courses with Osiander lasted for three months, and were taken by students who were also in the normal class, often by repeaters. Sometimes, young doctors from outside Göttingen had a privatissimum for a few weeks only, or even just a few hours, if they were passing through. It appears that hands-on practice was the main component of these private lessons. Occasionally, Osiander explicitly stated that the privatissimum provided experience in obstetric interventions. Of course, the phantom was used in this context, but experience of real deliveries was even more crucial. The lists of participants in Osiander's privatissima for five semesters between the winters of 1797/98 and 1800/01 still exist, and, in spite of some gaps in the birth records, it can be seen that each of the 22 participants was in charge of at least one delivery. Half of them are even mentioned as birth attendants several times during the period of their privatissimum. During all their time at Göttingen University, out of these 22 students, only 5 took care of just one delivery, 7 were in charge of two, 5 of three, and 2 of four. One attended five births, another nine, and a third student eleven. On average, therefore, each of the privatissimum students took care of three births. Clearly a private course with Osiander greatly enhanced a student's chances of assisting at a delivery in the hospital (see Table 2). In fact, in 1801 complaints were made to the Hanover government that Osiander gave too few opportunities for gaining

\footnotetext{
${ }^{98}$ This is true for the winter semester $1797 / 98$, summer 1798, winter 1799/1800, summer 1800, winter 1800/01; AUFK Gö, I 3 (Kalender 1798); Osiander, Annalen, op. cit., note 7 above, vol. 1, part 1, 1800, p. 166 ; vol. 2 , part 1,1801 , p. 142 ; vol. 2 , part 2,1804 , p. 322 .

${ }^{99}$ AUFK Gö, W 29, fols 25-6. As a rule, the professors of Göttingen University were supposed to teach four hours per week "publicly" free of charge. But the main courses were "private", and students had to pay for them. The fee was usually 3 taler per course in the theological and philosophical faculty, 5 taler in the juridical and medical faculty, 10 taler for practical exercises. Osiander insisted that this money had to be paid in advance, in accordance with the recently established University rules. He threatened not to allow anyone to participate who had not already paid, and announced that the seats would be distributed in the order of registration. The last point may have been an egalitarian rule, since in other courses, or earlier in the eighteenth century, the best seats were for noblemen,
}

who paid higher fees. For the summer semester 1796, Osiander posted the seating order of his lecture course, distributing the 36 students to seven tables; ibid., fol. 27. Regarding tuition fees at Göttingen University, which had a reputation for high charges, see Stefan Brüdermann, Göttinger Studenten und akademische Gerichtsbarkeit im 18. Jahrhundert, Göttingen, Vandenhoeck \& Ruprecht, 1990, pp. 310-16.

${ }^{100}$ On the open market system prevailing in London during the eighteenth century, see Susan C Lawrence, Charitable knowledge: hospital pupils and practitioners in eighteenth-century London, Cambridge University Press, 1996; Cody, op. cit., note 36 above, pp. 161-4; Irvine Loudon, Medical care and the general practitioner 1750-1850, Oxford, Clarendon Press, 1986, pp. 48-53. 


\section{The Practice of Practical Education}

hands-on experience in his normal "private" lectures, and thus students were compelled to enrol in a privatissimum with him. The professor was admonished and told to ensure that all his students received equal opportunities for such practical exercises and to avoid anything that could be interpreted as pressure on them to take a privatissimum. $^{101}$

What chance, then, did ordinary students have of being actively involved in a delivery? By comparing the lists of students with the names of birth attendants in the hospital diaries and calendars for periods when the records do not have major gaps, we can estimate how many of those who enrolled in Osiander's course never took part in any delivery at the hospital. For seven semesters between the summer of 1793 and winter of 1800/01, there were 209 students. Out of these, 72 (34.4 per cent) were never mentioned in the birth protocols. ${ }^{102}$ Therefore, the estimate is that a third of Osiander's students never had any hands-on experience in a delivery.

A similar calculation can be done for the midwife apprentices. For five courses between the winters of 1796/97 and 1800/01, there are lists, either handwritten or published by Osiander, containing a total of 23 names. ${ }^{103}$ For six more quarters between 1793 and 1797 , we have the number of apprentices (Table 1, col. 5) and the records of deliveries with the names of the birth attendants without major gaps. There is, thus, detailed evidence of a total of 36 apprentices, of whom only four (11.1 per cent) are never mentioned as birth attendants. These four took part in the spring course of 1800 , which had eight participants. So the proportion of learners who were never in charge of any delivery was three times higher among Osiander's male students than among his female apprentices, one in three, as compared to one in nine.

Of the 434 students who did act as birth attendants in the University hospital, more than half took care of only one delivery (Table $2 \mathrm{a}$, col. 2). Less than a quarter were in charge twice, just one out of ten, three times, and one out of twenty, four times. In this respect, too, female midwife apprentices had better access to practice (Table 2a, col. 5). Just over onethird of those who were actively involved in hospital deliveries were given only one such

\footnotetext{
${ }^{101}$ UnivA Gö, Kur. 4731, fol. 9. In reply, Osiander admitted that he could not always guarantee an even distribution of opportunities for assisting in deliveries between his sixty or seventy students. He insisted, however, that blame for any shortcomings lay not with him, but rather with those students who lacked diligence, or circumstances beyond his control, see fols 33-8. See also Wolff, op. cit., note 93 above, pp. 70-1.

${ }^{102}$ The students who, as repeaters, are registered in several of these lists have been counted only once. The calculation is based on students enrolled for the semesters of summer 1793, winters 1793/94 and 1795/ 96 , summer 1796 , winter $1799 / 1800$, summer 1800 , winter 1800/01. For the last three semesters, the lists are available in print: Osiander, Annalen, op. cit., note 7 above, vol. 1, part 1, 1800, pp. 164-6; vol. 1, part 2, 1801, pp. 91-5; vol. 2, part 2, 1804, pp. 320-1. In addition to the births in the maternity hospital, Osiander occasionally took students to home deliveries of poor women, and let them practise there; Friedrich Benjamin
}

Osiander, Kurze Übersicht der Vorfälle in dem Königl. Entbindungshospitale auf der Georg-AugustusUniversität zu Göttingen vom 1. April bis 31.[sic] September 1795 ..., Göttingen, n.d., p. [2]. This occurred mainly within the framework of the general medical Clinicum, which consisted mainly of consultation hours for poor patients, and was directed by Osiander 1792-1802. Such deliveries of outpatients are usually not recorded in the surviving documents, and appear to have been rare.

${ }^{103}$ AUFK Gö, A 1 (Tagebuch, vol. 4), fols 362-3; ibid., I 3 (Kalender 1798); Osiander, Annalen, op. cit., note 7 above, vol. 1, part 1, 1800, p. 167; vol. 1, part 2, 1801, pp. 95-6; vol. 2, part 2, 1804, p. 322. From these sources, it appears that in the winters of 1796/97, 1797/ $98,1799 / 1800$ the courses lasted from December to March, so that the same apprentices are included twice in the statistics, in the last quarter and in the first quarter of the following year (Table 1, col. 5). 


\section{Jürgen Schlumbohm}

Table 2(a)

Male students and female apprentices, by number of deliveries attended ${ }^{1}$ at the lying-in hospital of Göttingen University, 1793-1814

\begin{tabular}{l|c|c|c|c|c|c}
\hline $\begin{array}{l}\text { Number of } \\
\text { deliveries } \\
\text { attended }\end{array}$ & Number & $\begin{array}{c}\text { Male students of those } \\
\text { who attended } \\
\text { at least 1 } \\
\text { delivery }\end{array}$ & $\begin{array}{c}\text { Estimated \% } \\
\text { of all male } \\
\text { students }\end{array}$ & Number & $\begin{array}{c}\text { \% of those } \\
\text { who attended } \\
\text { at least 1 } \\
\text { delivery }\end{array}$ & $\begin{array}{c}\text { Estimated \% } \\
\text { of all female } \\
\text { apprentices }\end{array}$ \\
\hline 0 & $(1)$ & $(2)$ & $(3)$ & $(4)$ & $(5)$ & $(6)$ \\
1 & & & $34.4^{2}$ & & & $11.1^{3}$ \\
2 & 229 & 52.8 & 34.6 & 42 & 35.0 & 31.1 \\
3 & 105 & 24.2 & 15.9 & 25 & 20.8 & 18.5 \\
4 & 42 & 9.7 & 6.3 & 18 & 15.0 & 13.3 \\
5 & 23 & 5.3 & 3.5 & 12 & 10.0 & 8.9 \\
6 and over & 16 & 3.7 & 2.4 & 8 & 6.7 & 5.9 \\
\hline $\begin{array}{l}\text { Total of those } \\
\text { who attended at }\end{array}$ & 434 & 4.4 & 2.9 & 15 & 12.5 & 11.1 \\
least 1 delivery & & & & 120 & & \\
\hline
\end{tabular}

opportunity, and one out of five attended two births. Fifteen per cent assisted in three cases, 10 per cent in four, and 12.5 per cent in more than five.

If those who were never actively involved in a birth during their time at the hospital are taken into account (Table 2a, cols. 3 and 6), it is evident that more than two-thirds of the medical students attended no more than one delivery. Less than one-sixth took care of two, and even fewer were those involved in three or more births. Out of the female apprentices, however, almost 60 per cent assisted with at least two births, over 25 per cent with four or more births.

Among the medical students actively involved in deliveries, the average number of births attended per student was two, but for the midwife apprentices it was three. Taking into account those who were never actively involved, the average is 1.4 for male students, and 2.6 for female apprentices (Table 2b). This shows that in order to have training conditions comparable to those of the midwives-i.e. small groups and ample access to practise, in particular attendance at deliveries - the students were obliged to pay for a privatissimum; but only a small minority could afford such classes.

Given Osiander's insistence that the training of male medical practitioners was the main purpose of the University's lying-in hospital, these figures come as a surprise. They are a significant indicator of the extent to which students and apprentices assisted at deliveries, but of course they do not tell the whole story about practical education. Equally important is the content of the training. 


\section{The Practice of Practical Education}

Table 2(b)

Average number of deliveries attended by male students and female apprentices

\begin{tabular}{l|c|c}
\hline & Male students & Female apprentices \\
\hline $\begin{array}{l}\text { Average of those who attended at least 1 delivery } \\
\text { Estimated average of all (incl. those who did not } \\
\text { attend a delivery) }\end{array}$ & 2.1 & 3.0 \\
\hline
\end{tabular}

${ }^{1}$ Attending a delivery is defined here (and in the text) as being mentioned in the hospital diaries or calendars, which normally means being actively involved, either "assisting" the parturient woman or doing an operation, not merely looking on. Occasional visitors, students of law, etc. are excluded, although they are sometimes mentioned by name in the sources used.

This table may have a small bias, underestimating the number of deliveries attended by students. Midwife apprentices usually stayed for only three months at the hospital, whereas a considerable minority of the students stayed for more than one term. For this reason, more students than apprentices included in this table may have attended an additional birth during the periods when there are gaps between the different sources. If such a bias exists, it slightly exaggerates the difference between students and midwives.

${ }^{2}$ The estimated percentage of male students who did not attend a delivery is based on a total of 209 students in nominative lists for seven semesters between summer 1793 and winter 1800/01. See text and note 102 for details.

${ }^{3}$ The estimated percentage of female apprentices who did not attend a delivery is based on a total of 36 apprentices mentioned either in nominative lists or in statistical reports for eleven courses between 1793 and winter 1800/01. See text and note 103 for details.

Sources: AUFK Gö, A 1-8 (Tagebücher, vol. 4, 6-7, 10-14); I 1-3 (Kalender 1793, 1794, 1798).

In this regard, we do know that students and midwives were not trained in exactly the same hands-on skills during deliveries. As in the theoretical part of the course and in the exercises with the phantom, the emphasis for female apprentices was on assisting "natural" births. When a midwife was the only attendant mentioned in the medical case book, the Latin summary, placed in the margin of each protocol, usually read : "Partus naturalis. Assist[it] Fr[au] Meissnerin", "Natural birth, Mrs Meissnerin assisted", or, with slightly more detail: "Partus praematurus naturae viribus finitus. Assist[it] Fr[au] Hillin", "Premature birth, finished by the forces of nature. Mrs Hillin assisted". ${ }^{104}$ How exactly the apprentice assisted, is hardly ever specified. Osiander considered the midwife's task as routine, not worth a mention in his diary. If both a female and a male attendant are noted in a protocol, the Latin summary most commonly reports that the student performed an operation (op[era]t[ionem] fec[it]), and the apprentice assisted. While the former's operation is described precisely in the German transcript, the latter's help is generally veiled in silence. The few exceptions to this illustrate the distribution of tasks between midwife and medical student, and sometimes also between professor and student: "Since the head

${ }^{104}$ AUFK Gö, A 1 (Tagebuch, vol. 4), nos. 283 (1796) and 307 (1797). 


\section{Jürgen Schlumbohm}

would not advance, I had Mr Schlemm apply the forceps, who finished the birth (of the head) by 8 tractions. Mrs. Kling[en]b[ergin] received the child." ${ }^{105}$ Another responsibility for the midwife, in the case of a forceps operation, was supporting the perineum. "The labour pains were violent, and the head had advanced a great deal, but finally came to a halt. Therefore, I had Mr Werner apply the forceps and move the head by several tractions until it began to come through. Then we left it to nature, but the head did not advance any further. Instead, it receded again and again, because of narrow genitals. Therefore I applied the forceps once more, while the midwife Hübnerin was sitting in front [of the patient] and supporting [the perineum] ...". 106

In general, there are few references in Osiander's diary to the apprentices doing anything apart from waiting and receiving the child, but occasionally there is a passing mention of their performing other tasks. For example, in one case, Mrs "Seidin dilated the mouth of the uterus" before a student applied the forceps. ${ }^{107}$ In some other cases, an apprentice seems to have unwrapped the umbilical cord from the child's neck, probably after the head, but before the body, had come through. ${ }^{108}$

Using the phantom, Osiander taught midwives how to deliver a child presenting by the feet or the breech, and apparently even how to turn a foetus in the uterus, ${ }^{109}$ but the medical case books contain hardly any indications that he allowed them to practise these manoeuvres during real births. On Sunday, 20 September 1812, however, the apprentice Frau Sievertin alone helped in the birth of a girl presenting by the breech. Osiander explicitly noted in the hospital diary that she "freed" the arms and "pulled out the head". But he added that he was absent at the time. Similarly, in the late evening of 9 March 1814, "a premature girl ... presenting by the breech" was born "quickly and easily ... without any help", apparently more quickly than expected, for the patient was not even led to the birth stool in the delivery room, but gave birth in her chamber. Here too, only an apprentice, Frau Klapprothin, is noted as assisting, and the protocol seems to imply that Osiander did not come down in time from his apartment on the second floor of the hospital. ${ }^{110}$ He frequently committed cases where the child presented the head in a "perverse" way, such as face

\footnotetext{
${ }^{105}$ AUFK Gö, A 3 (Tagebuch, vol. 7), no. 87 (1801):

"Da der Kopf nicht fortrücken wollte, ließ ich $\mathrm{H}[\mathrm{e}] \mathrm{r}[\mathrm{rn}]$ Schlemm die Zange anlegen, der auch mit 8 Trakt[ionen] die Geburt des Kopfes [the last two words have been added later] endigte. Fr[au]

Kling[en]b[ergin] hob das Kind heraus ...". In another case, Osiander extracted the child's head with the forceps, and had the apprentice pull out the body; A 5 (Tagebuch, vol. 11), no. 46 (1808).

${ }^{106}$ AUFK Gö, A 6 (Tagebuch, vol. 12), no. 53 (1810): "Die Wehen waren heftig, und der Kopf war tief herabgerückt, blieb aber endlich stehen. Ich ließ daher $\mathrm{H}[\mathrm{e}] \mathrm{r}[\mathrm{rn}]$ Werner die Zange anlegen, und den Kopf ins Einscheiden mit etl[ichen] Tract[ionen] bringen. Da der Kopf aber dennoch nicht fortrückte, nachdem wir ihn im Durchschneiden der Natur überlassen hatten, vielmehr wegen Enge d[er] Genital[ien] immer wieder zurückwich, so legte ich noch mal die Zange an, wahrend die Hebamme Hübnerin vorsaß u[nd] unterstützte ...". Similar cases
}

are in AUFK Gö, A 6, no. 105 (1811), and A 5 (Tagebuch, vol. 11), no. 55 (1808).

${ }^{107}$ AUFK Gö, A 2 (Tagebuch, vol. 6), no. 605 (1800): "Seidin dehnt d[en] M[utter]m[un]d aus." In spite of that, she was not mentioned in the Latin summary on the margin of the protocol, in contrast to the student who was noted there as doing the operation (opt.fec.), together with "P[rofessor] O[siander]".

${ }^{108}$ AUFK Gö, A 2 (Tagebuch, vol. 6), no. 596 (1800); A 3 (Tagebuch, vol. 7), no. 1 (1801); A 4 (Tagebuch, vol. 10), no. 26 (1806) and 81 (1807). In these cases, the protocol does not explicitly say who removed the wrapped umbilical cord, but the midwife apprentice is the only birth attendant mentioned.

${ }^{109}$ See above note 56 and related text.

${ }^{110}$ AUFK Gö, A 7 (Tagebuch, vol. 13), no. 142: "Partus natibus praeviis, adiuv[it] Fr[au] Sievertin." "... auf einmal aber trat heute, me absente, der Hintere ein, und kam von selbst hervor. Die Arme lösete Fr[au] Sievertin. ... die Fr[au] S[ievertin] hob d[en] Kopf 


\section{The Practice of Practical Education}

presentations, to the midwife apprentices, ${ }^{111}$ but breech and foot presentations, and certainly versions, were normally dealt with by the professor himself or by medical students. Thus, in a twin birth on 8 January 1800, the first child, presenting the head, was delivered by the apprentice Frau Hakfeldin; however, the second child, presenting the feet, was delivered by Osiander and Mr van den Bosch, a student from The Hague (Netherlands). As usual, the midwife's actions are not specified, while those of the student and the professor are recorded: "At 10 [p. m.] the mouth of the uterus was completely open. At 10.15 [p.m.] birth of the first child. The second child presented the feet. At 11.15 [p.m.], I had Mr van $\mathrm{d}$ [en] Bosch grip the feet, but I ruptured the amniotic sac myself. Mr v[an] d[en] B[osch] pulled out the child up to the shoulder, freed the arms, I pulled out the head." 112

Regarding the medical students, the teaching concern most visible in Osiander's case books was to show them how to use the forceps, for he was firmly convinced that a forceps operation, performed skilfully, was the best assistance in most protracted and difficult births. Although leading English obstetricians had opposed this view since the mid-eighteenth century, and even French accoucheurs were beginning to give it up, Osiander proudly declared in print that he hardly ever let a lingering or painful delivery, "whether caused by the umbilical cord wrapped around the foetus, or by a first degree of obstruction, slip by without the forceps being applied, either by myself in front of the students, or by a student who is already well-practised on the phantom". This was not an overstatement. In the thirty years for which he directed the maternity hospital of Göttingen, the forceps were used in 40 per cent of all deliveries. ${ }^{113}$

Osiander had several ways of training students in use of the instrument. In some deliveries, he first "demonstrated how to apply the forceps, took them out again, let" the student "apply them again" and make tractions. ${ }^{114}$ In other cases, the professor had the student introduce the first blade of the forceps, and applied the second one himself. "Thereby", he explained in a protocol, "one saw how much depended on the skill

vollends hervor." A 8 (Tagebuch, vol. 14), no. 100: "Partus praematur[us] natibus praeviis celer. Assist[it] Fr[au] Klapprothin." "Abends 8 Uhr bekam sie die ersten Wehen, und um 10 Uhr war d[er] $\mathrm{M}[\mathrm{utter}] \mathrm{m}[\mathrm{u}]$ nd noch nicht völlig offen, um $\mathrm{h}[\mathrm{alb}]$ 10 brachen die Wasser, und ein weicher Teil, der Steiß, wurde vorliegend gefühlt. Nachts halb $11 \mathrm{Uhr}$ kam das Kind, ein zu frühzeitig geborenes Mädchen, schnell u[nd] leicht mit d[em] Hintern, der ganz blau u[nd] geschwollen war, ohne alle Hülfe zur Welt, ehe die Gebär[ende] auf d[en] Stuhl gebracht werden konnte, auf ihrer Stube."

${ }^{111}$ See, e.g., ibid., A 2 (Tagebuch, vol. 6), no. 596, 611, 619; A 3 (Tagebuch, vol. 7), no. 1, 4; A 4

(Tagebuch, vol. 10), no. 78; A 7 (Tagebuch, vol. 13), no. 5, 53, 63; A 8 (Tagebuch, vol. 14), no. 35.

${ }^{112}$ Ibid., A 2 (Tagebuch, vol. 6), no. 576: "Partus gemellorum, alter capite, alter pedibus praeeunte. Ass[istit] 1. Fr[au] Hakfeldin, 2. H[er]r van den Bosch." "Um 10 Uhr [abends] war der M[utter]m[u]nd völlig offen; um 1/4 nach 10 Uhr Geburt des ersten Kindes. Das 2te Kind lag mit den Füßen vor. Um 1/4 nach 11 Uhr ließ ich $\mathrm{H}[\mathrm{er}] \mathrm{rn}$ van $\mathrm{d}[\mathrm{en}]$ Bosch die Füße ergreifen, sprengte aber selbst die Wasser,
$\mathrm{H}[\mathrm{er}] \mathrm{r}$ v[an] d[en] B[osch] zog das Kind bis an die Schulter hervor, lösete die Arme, ich hob d[en] Kopf heraus."

${ }^{113}$ Schlumbohm, 'Pregnant women', op. cit., note 5 above, pp. 70-2; Osiander, Denkwürdigkeiten, op. cit., note 21 above, vol. 1, part 1, pp. CX-CXI: "Ich lasse daher nicht leicht eine aus Umschlingung oder anderer Ursache verzögernde und schmerzhafte Geburt oder den ersten Grad der Einkeilung unbenutzt

vorübergehen, ohne die Zange entweder selbst vor den Augen meiner Zuhörer anzulegen oder durch einen von den am Phantome schon Wohlgeübten anlegen zu lassen." In Osiander's view, use of the forceps was firmly linked to a rejection of embryotomy, see above note 42 and related text. As for English and French obstetricians' attitude to the forceps, see Wilson, op. cit., note 36 above, pp. 167-8, 177-80; Gélis, op. cit., note 36 above, pp. 345-57.

${ }^{114}$ AUFK Gö, A 3 (Tagebuch, vol. 7), no. 101 (1801): "Ich ... zeigte das Anlegen d[er] Zange, nahm sie wieder heraus, ließ H[er]r[n] D[r] Reuss dieselbe wieder anlegen ... und mit 26 Tract[ionen] die Geb[urt] d[es] K[o]pf[es] mit d[er] Z[ange] endigen." Similarly, nos. 36, 67 and 88 (1801). 


\section{Jürgen Schlumbohm}

with which the forceps were held and directed". ${ }^{115}$ On other occasions, Osiander took over only after his disciple's attempts failed. In a "slow and painful birth" on 30 December 1806, "the parturient woman became tired and asked for help. ${ }^{116}$ Therefore, I had D[r] Daeubler apply the forceps, introduced the second blade, however, myself, because he could not introduce it." Similarly, on the very next day, Mr von Walther, a student from Livonia, one of the Baltic Provinces of the Russian empire, was only partially successful in a "birth that was slow because of inertia of the uterus": "... the forceps are applied. I introduce the second blade myself, because $\mathrm{Mr}$ v[on] W[alther] missed the bend and could not apply it. Then he finished the operation happily with 23 tractions." In another protracted delivery, "I had Mr Hiller apply the forceps. He introduced only the first blade successfully, the second, however, buckled. Hence I took over, did some standing tractions, and had D[r] Hiller do the remaining larger number [of tractions]. About 18 standing and 25 sitting [tractions] were necessary to pull out the head." 117

The aim was to apply the forceps quickly and painlessly. ${ }^{118}$ But sometimes the professor was very patient with his students, letting them try again and again. As usual, he did not record the woman's reactions to this treatment. "Since at midnight the head had not yet advanced further, I had the forceps applied, but Mr Block was unable to introduce them. Therefore, I applied them first, pulled down the head with about 20 standing tractions, let Mr Block try to apply the forceps, but again it did not work. Therefore I applied them for the second time, pulled the head down even more. At last, the third time, Mr Block succeeded, he did about 12 tractions, sitting." ${ }^{119}$ In another case, Osiander let several students try to introduce the forceps, and only the third one managed to do so. ${ }^{120}$

\footnotetext{
${ }^{115}$ AUFK Gö, A 1 (Tagebuch, vol. 4), no. 266 (1796): "Die 2te Branche legte ich selbst an, und man sahe dabei, wie viel es aufs geschickte Halten und Führen d[er] Zange ankam." Cf. no. 296 (1796).

${ }^{116}$ For Osiander, a patient's wish for artificial help was not a sufficient reason, but only a supporting point, for intervening. That is, at least, how his case histories are stylized; Schlumbohm, 'Blick', op. cit., note 75 above, pp. $186-87$.

${ }^{117}$ AUFK Gö, A 4 (Tagebuch, vol. 10), no. 67: "Partus ... tardus et dolorificus ... Op[era]t[ionem] fec[it] D[ominus] Dr. Daeubler." “... die Gebärende ermüdete und bat um Hülfe; ich ließ daher H[er]r[n] $\mathrm{D}[\mathrm{r}$.] Daeubler die Zange anlegen, brachte aber die 2te Branche selbst ein, weil er diese nicht einbringen konnte." No. 57: "Partus ob inertiam uteri lentus forcipe feliciter absolutus. Op[era]t[ionem] fec[it] $\mathrm{D}$ [omi]n[us] von Walther, Livonus." “... daher die Zange angelegt wird, die 2 te $\mathrm{Br}$ [anche] bringe ich selbst ein, weil d[er] H[err] v[on] W[alther] die Umbieg[ung] verfehlte und sie nicht beibringen konnte; mit 23 Tract[ionen] endigte er dann die Op[era]t[ion] glückl[ich]." A 3 (Tagebuch, vol. 7), no. 171 (1802): "Ich ließ daher H[er]r[n] Hiller die
}

Zange anlegen; allein das erste Blatt brachte er gut ein; das 2te aber warf sich; daher übernahm ich das Anlegen, machte einige stehende Tract[ionen]; und ließ $\mathrm{H}[\mathrm{er}] \mathrm{r}[\mathrm{n}] \mathrm{D}[\mathrm{r}]$. Hiller die übrigen meisten machen. C[ir]c[a] 18 stehende und 25 sitzende waren notwendig, den Kopf zu Tag zu bringen." In his textbook for medical men, Osiander gave detailed advice on how to apply, and do tractions with, the forceps: Grundriss, op. cit., note 29 above, vol. 2, pp. 22-33.

${ }^{118}$ Ibid., pp. 24-6.

${ }^{119}$ AUFK Gö, A 4 (Tagebuch, vol. 10), no. 142 (1807): "Da um Mitternacht der Kopf noch nicht weitergerückt war, so ließ ich die Zange anlegen, aber $\mathrm{H}[\mathrm{er}] \mathrm{r}$ Block vermochte sie nicht einzubringen; ich legte sie daher zuerst an, zog den Kopf mit c[ir]c[a] 20 steh[enden] Tract[ionen] herab; ließ H[er]r[n] Block $\mathrm{ab}[\mathrm{er}] \mathrm{d}[\mathrm{ie}] \mathrm{Z}$ [ange] anzuleg[en] versuchen, aber es glückt[e] wied[er] nicht. Ich legte sie daher z[um] 2ten Mal an, zog den Kopf noch tiefer. Endlich z[um] 3ten Mal gelang es $\mathrm{H}[\mathrm{er}] \mathrm{r}[\mathrm{n}]$ Block, er machte sitzende Tract[ionen] c[ir]c[a] 12 ...".

${ }^{120}$ AUFK Gö, A4 (Tagebuch, vol. 10), no. 10 (1806). 


\section{The Practice of Practical Education}

Applying the forceps was not the only difficulty. How to perform the tractions correctly also had to be learnt by trial and error. "Mr Österle applied the forceps, did some tractions, but since he bent them upwards too early, the forceps slipped away." Osiander took over and showed how to do the operation correctly. ${ }^{121}$ In another case, the student applied the forceps and did about fifty tractions, "but once, when he lifted [the forceps] too much, they threatened to slip away". Osiander let him apply the instrument again, and only later took over and finished the operation. ${ }^{122}$ In yet another birth, the professor had Mr Kübler apply the forceps, but realized that "the case was too difficult for a beginner". In fact, it was the first, and incidentally the only, birth attended by this student. Thus, Osiander "took over the operation myself, and finished the delivery with many firm, strong, and, because of the narrow outer genitals, careful pulls."123

Often, Osiander and one or several students alternated and cooperated in a delivery. In a difficult birth during the night of 11/12 June 1801, the professor "dilated the mouth of the uterus with my dilatator, applied the forceps ... took out the forceps again, had $\mathrm{Mr}$ Albrecht apply [them]. But since at first he did not manage to do this, I had Mr Reuß apply [them], who introduced them after some attempts. Now Mr Albr[echt] did tractions. Since the forceps deviated a little too far, he took them out again, applied them well this time, and finished the birth with 47 tractions." 124 During the night of 20/21 July 1807, a patient was in labour who in 1804 had already been delivered by a long forceps operation in the Göttingen hospital because she had a very narrow pelvis. The professor "predicted to my students that we had to be prepared for a difficult delivery, and announced what we would do now". He performed the most complicated tasks himself, but sought to delegate to the student as much as possible. "I had Mr Steiner break the amniotic sac with his fingers". Then "the position of the head was examined. The occiput stood above the left acetabulum. Mr Steiner was supposed to pull it down and apply the forceps. He did not succeed in introducing the second blade, however, because of the high position of the head. Therefore, I took over applying them, and then had him do standing tractions. We alternated in this, but the head would not go down into the pelvis." Now Osiander tried to find a better way to apply the forceps, but in vain, "partially because of the narrow pelvis, partially because the woman in labour did not help by any effort on her part". ${ }^{125}$ At last, during a heavy contraction, Osiander managed to pull down the occiput, apparently with his hand. He applied the forceps again, did tractions standing and sitting, "had the

${ }^{121}$ AUFK Gö, A 3 (Tagebuch, vol. 7), no. 55 (1801): “. . . dann legte H[er]r Österle die Zange an, machte einige Tract[ionen], aber weil er zu frühe aufbog, gleitete die Zange ab. Ich legte sie hernach an, machte stehende Tract[ionen], bog sie in schief[en] Durchmesser rechts auf ...".

${ }^{122}$ AUFK Gö, A3 (Tagebuch, vol. 7), no. 123 (1802): “ . . . aber die Zange wollte, da er einmal zu hoch aufhob, abgleiten."

${ }^{123}$ AUFK Gö, A 7 (Tagebuch, vol. 13), no. 149 (1812): "Ich ließ H[er]rn Kübler die Zange anlegen, aber da der Fall für einen Anfänger zu schwer war, übernahm ich die Op[era]t[ion] selbst und vollendete mit viel schweren, kräftigen und wegen Enge d[er] äuß[eren] Genit[alien] behutsam verrichteten Zügen die Geburt."

${ }^{124}$ AUFK Gö, A 3 (Tagebuch, vol. 7), no. 34: "Ich dehnte d[en] M[utter]m[u]nd mit m[einem] Dilatatorio aus, legte die Zange an ..., [deleted: zog d] nahm die Zange wieder heraus, ließ $\mathrm{H}[\mathrm{e}] \mathrm{r}[\mathrm{rn}]$ Albrecht anlegen. Da aber dieser anfangs nicht zurecht kam, [deleted: legte ich] ließ ich $\mathrm{H}[\mathrm{e}] \mathrm{r}[\mathrm{rn}]$ Reuß anlegen, der nach einigen Versuchen sie einbrachte. Nun machte $\mathrm{H}[\mathrm{er}] \mathrm{r}$ Albr[echt] Tractionen, nahm, da die Zange etwas zu weit abkam, sie wieder heraus, legte sie nun gut an und vollendete die Geburt mit 47 Tractionen."

${ }^{125}$ This extraordinarily difficult delivery is one of the rare cases where the professor mentioned in the diary that the parturient woman was supposed to play an 


\section{Jürgen Schlumbohm}

mouth of the uterus pushed upwards", and after many more efforts- "according to several persons present a total of 103 tractions had to be done" - at last he could move the head down. "Now I had Mr Steiner finish the birth, who in fact artfully completed pulling out the head and the body." ${ }^{126}$ In the protocol of a birth, on 25 August 1808, which was "very difficult because of the narrow pelvis and the large head", Osiander admitted to having called on the help of a student, whereas normally he was the one who guided, and if necessary helped, his students. In this case, he first vainly tried to lead the occiput down into the pelvis with his hand, then did a podalic version. When he pulled the feet forcefully, the head did not follow. At last, he got the child into a position where he could apply the forceps, did "about 60 [tractions], and Mr Hering probably did 20 to 30, but still the head did not move. At last Mr Borchers volunteered, who according to his fellow students was the strongest of them. I accepted, but admonished him to be very careful. With only the second traction, however, he pulled the head out of the genitals, with a jerk. The perineum was partially ripped open, bled a lot, and fits of fainting followed." The child was dead. The next day, Osiander found that the fissure in the perineum went right down to the anus, and sewed it up. He reported that the wound had healed completely by the time the woman left the hospital on 28 September, and that he had shown this to his students. ${ }^{127}$

As this case shows, there were risks involved, especially when inexperienced students did a forceps operation. Several times, the perineum was lacerated. ${ }^{128}$ For precisely this reason, the professor sometimes took over and did the last tractions himself. ${ }^{129}$ Another risk implied in forceps operations was that the child could be moved into a worse position when the instrument was introduced into the uterus. ${ }^{130}$ If this happened, it was usually, according to the protocol, the fault of an inexperienced student. In other cases, such as the

active part in the birthing process. Normally, in the birth protocol, she appears rather as the object of the obstetrician's and his students' activities; Schlumbohm, 'Blick', op. cit., note 75 above, p. 181.

${ }^{126}$ AUFK Gö, A 4 (Tagebuch, vol. 10), no. 83: "[Ich] sagte $m$ [einen] Zuhörern voraus, dass wir uns auf eine schwere Entbind[ungs]arbeit gefasst machen mussten und was wir nun tun wollten. [Ich ließ] $\mathrm{H}[\mathrm{e}] \mathrm{r}[\mathrm{rn}]$ Steiner mit d[en] bloßen Fingern die Wasser sprengen. [Dann] wurde der Kopfstand untersucht: Das Hinterhaupt stand über dem linken Acetabulo. H[er]r Steiner sollte es herabziehen und die Zange anlegen. Allein die 2te Br[anche] einzubringen wollte ihm bei dem hohen Kopfstand nicht gelingen. Ich übernahm daher das Anlegen und ließ ihn nun stehende Tract[ionen] machen. Wir wechselten darin miteinander ab, allein d[er] Kopf wollte durchaus nicht ins Becken herab. ... wiederholte Versuche waren vergeblich, teils wegen Enge des Beckens, teils weil die Kreißende durch keinen Effort von ihrer Seite anhalf. [Ich] ließ den M[utter]m[u]nd an der Vorderwand in die Höhe schieben". "Es mussten nach d[er] Zählung verschied[ener] Anwesender 103 Tract[ionen] gemacht werden." "Ich ließ nun H[e]r[rn] Steiner die Geburt vollenden, der auch den Kopf u[nd] Leib vollends geschickt heraushob."
${ }^{127}$ AUFK Gö, A 5 (Tagebuch, vol. 11), no. 30: "Partus ob angustiam pelvis et magnitudinem capitis perdifficilis". ". . . ich machte wohl 60, H[er]r Hering wohl 20-30 [Tractionen], aber der Kopf wankte nicht. Endlich bot sich Herr Borchers an, der unter d[en] Prakt[ikanten] die größte Stärke haben sollte, nach dem Urteil s[einer] Kommil[itonen]. Ich ließ es zu, ermahnte ihn aber zur großen Vorsicht. Aber schon mit dem 2ten Zug zog er den Kopf mit einem Ruck aus den Genitalien. Der Damm riss ein, blutete sehr, und es erfolgten Anwandlungen von Ohnmachten." Normally, patients left the hospital about two weeks after giving birth; Schlumbohm, 'Verheiratete und Unverheiratete', op. cit., note 45 above, pp. 334, 337. ${ }^{128}$ AUFK Gö, A 3 (Tagebuch, vol. 7), no. 125 (1802); A 4 (Tagebuch, vol. 10), no. 2 (1806).

${ }^{129}$ AUFK Gö, A 1 (Tagebuch, vol. 4), no. 290 (1797); A 6 (Tagebuch, vol. 12), nos. 9 (1810) and 175 (1811). Cf. Osiander, Grundriss, op. cit., note 29 above, vol. 2 , p. 31

${ }^{130}$ This is fairly explicit in AUFK Gö, A 4

(Tagebuch, vol. 10), no. 157 (1808), and seems to be implied elsewhere, e.g., A 3 (Tagebuch, vol. 7), nos. 123, 139, 146, 169 (1802); A 6 (Tagebuch, vol. 12), no. 104 (1810). 


\section{The Practice of Practical Education}

difficult deliveries of 11/12 June 1801 and 20/21 July 1807, the forceps left "an impression in the skin in the middle of the forehead" of the baby, or even "an impression" which "seemed deep" at first, and after several days still appeared as a "red strip". ${ }^{131}$ On another occasion, an os occipitale was incised, and, on still another, an impression of the forceps in the skin that had hardly been visible right after birth, developed into two holes in the scalp after three days, which became deeper and deeper. Both children died within twelve days. In a different case, the protocol seems to suggest that the asphyxia and death of the child were, at least in part, caused by a student who did forceps tractions in the wrong way. ${ }^{132}$

Apart from questions of life and death, it is not surprising that many students did not do really well when they first tried out on a living patient what they had previously practised on the dummy. The effective use of forceps could be learnt only by extensive practice, guided by an experienced practitioner. ${ }^{133}$ It should be borne in mind, however, that more than half of those students who were allowed to attend a delivery took care of only one birth during their time at the Göttingen hospital. This is also true for several of the students who, according to the protocols cited, were not really successful in their first practical endeavours: Walther, Kübler, Albrecht, Steiner and Borchers never had another chance in Göttingen, and Block, who did attend a second delivery later, then introduced only the first blade of the forceps, while the professor applied the second and pulled the child out. ${ }^{134}$

Foot and breech presentations do not seem to have been a major focus in Osiander's practical teaching. He took care of many of them himself, or committed them to his son Johann Friedrich (1787-1855), who first studied with him, later became his assistant, and was then made a professor of medicine in Göttingen, too. ${ }^{135}$ Once, he let a newly arrived privatissimum student pull out a child presenting the right foot, which was easy in this particular case, although the left leg was extended along the child's body in the womb. ${ }^{136}$ Osiander tended to turn breech presentations so the feet presented, ${ }^{137}$ and if he did not do this operation entirely by himself, he assigned only partial tasks to his students. Thus, on 18 July 1802, he carried out a podalic version and then had Dr Näff complete the birth by pulling the feet, although it was difficult to make the head pass. ${ }^{138}$ In another breech presentation, on 8 April 1813, the professor "got the feet down, and had Mr Plagge pull them. However, I myself undertook to free the shoulders. For, since the shoulders were

${ }^{131}$ AUFK Gö, A 3 (Tagebuch, vol. 7), no. 34: "Ein Eindruck in der Haut auf d[er] Mitte der Stirne"; A 4 (Tagebuch, vol. 10), no. 83: "Eindruck der Zange über dem rechten Stirnbeine. ... der Eindruck schien nicht mehr tief, sondern nur als roter Streifen." Cf. A 2 (Tagebuch, vol. 6), no. 615 (1800); A 3 (Tagebuch, vol. 7), no. 55 (1801); A 4 (Tagebuch, vol. 10), no. 10 (1806); A 6 (Tagebuch, vol. 12), no. 170 (1811). In his textbook, Osiander argued that all these "impacts of the forceps on the head are not detrimental to the child's life", and that only a maladroit use of the instrument was dangerous; Grundriss, op. cit., note 29 above, vol. 2, pp. 65-68.

${ }^{132}$ AUFK Gö, A 6 (Tagebuch, vol. 12), no. 15 (1810); A 2 (Tagebuch, vol. 6), no. 664 (1801), in this case the child's death was not recorded by Osiander in the Tagebuch, but only by the hospital manager in the admission book: C 1 (Aufnahmebuch, vol.1), no. 786; A 3 (Tagebuch, vol. 7), no. 18 (1801). A 4 (Tagebuch, vol. $10)$, no. 10 (1806) also implies that the child's death may have been caused by the forceps.

${ }^{133}$ Wilson, op. cit., note 36 above, pp. 71-2, 96. See also Osiander, Grundriss, op. cit., note 29 above, vol. 2 , p. 69-70.

${ }^{134}$ AUFK Gö, A 5 (Tagebuch, vol. 11), no. 55 (1808).

${ }^{135}$ Hirsch (ed.), op. cit., note 90 above, vol. 4, 1886, pp. 444-5.

${ }^{136}$ AUFK Gö, A 6 (Tagebuch, vol. 12), no. 130

(1811). See also above note 112 and related text.

${ }^{137}$ Osiander, Grundriss, op. cit., note 29 above, vol. 2, pp. 346-50.

${ }^{138}$ AUFK Gö, A 3 (Tagebuch, vol. 7), no. 154. 


\section{Jürgen Schlumbohm}

broad and the arms crossed, this was too difficult for a beginner." In fact, this was the first delivery attended by Martin Wilhelm Plagge, although he had been a student at Göttingen for two years. Osiander's protocol did not specify who slipped the umbilical cord, which passed between the two legs, over one foot. But it was he who applied the forceps in order to get the head out quickly. The Latin summary said accurately: "Professor Osiander did the operation, Mr Plagge helped."139

Most versions were done by Osiander or by his son, or by them both. But Osiander seems to have been particularly eager for his students to watch this type of delivery, for he frequently mentions in his case book that he started the operation only when the students had arrived. ${ }^{140}$ In the evening of 3 November 1814, he diagnosed a transverse presentation, but did not begin the manoeuvre of turning the child until "almost all the spectators, about 60 ", out of 65 had assembled. The complicated operation started with dilating the os uteri and breaking the amniotic sac, it included putting loops around the feet and pulling them down, and ended with applying the forceps for extracting the head. Evidently, the professor enjoyed the students admiring his virtuosity, and he added in the end of the protocol: "In a few minutes, the whole operation was finished" at 11 p.m., despite the fact that "the mother behaved very impatiently". ${ }^{141}$ This was the usual scenario for versions: the professor, centre stage, often with his son, and the students as spectators. If, however, one or several of them were assigned an active role, this was for limited tasks only, ${ }^{142}$ for example, Dr Näff in 1802 and Mr Plagge in 1813. Unlike forceps operations, versions were hardly ever performed by students. But one such case was given to Dr Joseph Friedrich Österle on Sunday, 17 May 1801. He had already attended four births in Göttingen, including two forceps operations, and in at least one of them he had done "very well". This time, the professor had diagnosed an elbow presentation. He had Österle dilate the mouth of the uterus and push the arms and the head upwards, so that the feet came down. The student tried unsuccessfully to attach the loop. Only then did Osiander intervene, introducing his hand into the womb and pulling the feet down. Then he let

${ }^{139}$ AUFK Gö, A 8 (Tagebuch, vol. 14), no. 8. Osiander proudly recorded that the whole operation took less than half an hour and could not refrain from adding that it would have been finished even sooner, if the parturient woman had not "behaved in a very fidgety way"; "Nach halb 6 Uhr holte ich die ... Füße herab, ließ sie H[er]rn Plagge anziehen; aber die Schultern zu lösen übernahm ich selbst, weil solches bei $\mathrm{d}[\mathrm{er}]$ Breite der Schult[ern] u[nd] gekreuzten Armen zu schwer für einen Anfänger war. Als die Füße herabgezogen waren, musste die zwischen $\mathrm{d}$ [en] Schenkeln durchgehende Nabelschnur über den rechten Fuß weggezogen werden ... Um schnell d[en] Kopf herauszubringen, legte ich die Zange an und zog ihn mit etl[ichen] Tract[ionen] aus. Die Gebärende betrug sich sehr unruhig, sonst wäre die Entbind[ung] noch schneller geendigt worden. Ende der Geburt um 6 Uhr abends." "Op[era]t[ionem] fec[it] Prof. Osiander, adjuv[it] d[omi]n[us] Plagge." Plagge attended one more delivery, where he applied the forceps and finished the birth happily by 15 tractions, on 26 April
1813; A 8 (Tagebuch, vol. 14), no. 15. He matriculated on 3 May 1811; Selle (ed.), op. cit., note 16 above, no. 23012. He later made a career as military surgeon, personal physician of noblemen, author of medical books, and professor of medicine at the University of Gießen; Hirsch (ed.), op. cit., note 90 above, vol. 4, 1886, pp. 582-3.

${ }^{140}$ AUFK Gö, A 3 (Tagebuch, vol. 7), no. 57 (1801), nos. 107, 136 (1802); A 4 (Tagebuch, vol. 10), nos. 2(1806), 86 (1807); A 5 (Tagebuch, vol. 11), no. 81 (1809); A 6 (Tagebuch, vol. 12), nos. 157, 158 (1811); A 7 (Tagebuch, vol. 13), no. 96 (1812).

${ }^{141}$ AUFK Gö, A 8 (Tagebuch, vol. 14), no. 158:

"Nachdem fast alle Zuschauer, c[ir]c[a] 60, beisammen waren ... Die Mutter betrug sich sehr ungedultig. ... In wenigen Minuten war die ganze Operation vollendet."

${ }^{142}$ AUFK Gö, A 3 (Tagebuch, vol. 7), no. 2 (1801); A 4 (Tagebuch, vol. 10), nos. 2, 15 (1806); A 6 (Tagebuch, vol. 12), no. 95 (1810); A 8 (Tagebuch, vol. 14), no. 61 (1813). 


\section{The Practice of Practical Education}

Österle finish the version, which he did very well until the head became visible, and the professor pulled it out. In this case, he had entrusted most of the operation to the student, as he often did if the forceps were to be applied, and helped out himself when the learner could not manage. ${ }^{143}$ A similar exception was the hand or foot presentation-Osiander was not sure which of the two- on 4 April 1804. There Osiander had Mr Dreyer do the whole operation, including turning the child, since he "was already well trained in the version, privatissime", on the phantom. Moreover, he had taken care of three deliveries before, one of them a forceps operation. The professor stated that the student did the operation "very cautiously and slowly" and did not "cause any special pain" to the patient, although she "behaved in a very unruly way and screamed a lot at the beginning". 144

Since Osiander committed versions to medical students in only exceptional cases, it is less surprising that he did not allow midwife apprentices to practise them on real patients, although in principle he wanted them to learn this operation, in case of emergencies. ${ }^{145}$ The difference between what he taught students on the one hand and apprentices on the other is much clearer with regard to his favourite operation, the forceps. It was a major focus in training students, but taboo for midwives. There was only one exception confirming the rule of this dichotomy: a woman who, under Osiander's direction, intervened with the forceps in all three deliveries that she took care of. She was Fräulein Charlotte Heiland, also named von Siebold. On 24 August 1812, in a "natural birth" the professor had her "apply the forceps just for a trial, and take them out again". In the protocol, he added a remarkably positive comment: "She applied them quite well, although she had had only a few lessons before." A month later, she introduced the forceps and "happily" pulled out the head with about six tractions. On 12 October 1812, when the professor was absent, his son had Fräulein von Siebold apply the forceps and finish the birth with twelve to sixteen tractions. On both occasions, her performance was assessed as "quite good" or "skilful". Osiander did record why he allowed this woman to use his favourite instrument: she was not a midwife apprentice, but "a student of the obstetric art". The reason she was admitted by the professors of the Göttingen medical faculty, including Osiander, to both their normal "private" and their "privatissima" lessons, even though she was not formally

\footnotetext{
${ }^{143}$ AUFK Gö, A 3 (Tagebuch, vol. 7), no. 31. For earlier births attended by Österle, see nos. 12, 17, 24, 25: "sehr brav" (April and May 1801). Later, he attended five more deliveries. He had already studied in Tübingen before he matriculated in Göttingen, 22 Oct. 1800; Selle (ed.), op. cit., note 16 above, no. 19226. In 1804 , he was town surgeon and man-midwife in the town of Kirchheim unter Teck, Württemberg, where Osiander had practised for several years before he was called to Göttingen University; Osiander, Annalen, op. cit., note 7 above, vol. 2, part 2, 1804, p. 321. Similarly, Osiander had committed a version to Dr Reuß, who had attended four deliveries before; AUFK Gö, A 2 (Tagebuch, vol. 6), no. 664 (12/13 March 1801).

${ }^{144}$ AUFK Gö, A 8 (Tagebuch, vol. 14), no. 111:

"Ich ließ ... H[er]r[n] Dreyer, der privatissime im
}

Wenden schon sehr geübt war, die Wasser springen, die Füße herabholen, das Kind wenden. ... Die Geburt endigte schnell und glücklich für die Mutter, ungeachtet sich diese sehr unbändig betrug und anfangs sehr schrie, obgleich ihr keine besond[eren] Schmerzen verursacht wurden und $\mathrm{H}[\mathrm{er}] \mathrm{r} \mathrm{D}$ [reyer sehr vorsichtig und langsam verfuhr." "Op[era]t[ionem] fec[it] D[omi]n[us] Dreyer." Earlier deliveries attended by Dreyer: nos. 86, 102, 109 (Dec. 1813-April 1814). He did not attend any subsequent births. A 4 (Tagebuch, vol. 10), no. 28 (1806): the student Dr Schnurrer did a podalic version alone when Osiander was not present, due to sickness. Schnurrer, too, had attended three deliveries before.

${ }^{145} \mathrm{Cf}$. above notes 56 and 109 and related text. 


\section{Jürgen Schlumbohm}

matriculated, was without doubt because, through her stepfather, she was part of the famous Siebold dynasty of medical doctors and professors. ${ }^{146}$

\section{Training Obstetricians and Midwives}

In several ways, the archival sources on practical education at the maternity hospital of Göttingen confirm Osiander's words that its first priority was the training of skilful obstetricians, and that the training of midwives was of only secondary importance. The number of medical students using the hospital by attending the professor's theoretical and practical course was much larger than that of female apprentices. Therefore, among all those who are mentioned as birth attendants in the hospital diaries or calendars, 78 per cent were male and only 22 per cent female. Moreover, the skills which the professor of obstetrics considered superior were reserved for medical students. This is true of "artificial help" in general, and the use of the forceps in particular.

If, however, we turn from this aggregate level to the experience of individual students and apprentices, the balance is less clear. Many medical students attended Osiander's lectures for only one semester, exercised a couple of times on the phantom, practised a few physical examinations, and watched a small number of births. One-third of his students never took part in any delivery in the hospital. Most of those who did were in charge of just one birth, and only a small minority, 5 per cent of all students, attended more than four deliveries. In this respect, midwife apprentices were clearly privileged. Since their number was much smaller, they did more exercises with the phantom, examined patients every week and took care of more births. Possibly, Osiander thought that, because of their limited theoretical capacities, more extensive practical experience in the hospital was required, if the traditional bad habits of uninstructed matrons, to which they were exposed in their local

\footnotetext{
${ }^{146}$ Her stepfather, Damian von Siebold, MD, and her mother Josepha von Siebold (née Henning, widow of Heiland), who practised as a medically instructed midwife, had taught Charlotte privately for two years before she attended Göttingen University from the end of 1811 to the fall of 1812 . Later, she practised midwifery, and her most famous case was the birth of the future Queen Victoria of England in 1819. In 1817 Charlotte graduated as a "doctor of obstetrics" from Gießen University. Then, Osiander's praise turned into hostility, since, in the theses which accompanied her doctoral dissertation on abdominal pregnancies, she argued for moderation in the use of the forceps, and did not reject embryotomy altogether. Osiander found this unworthy of a disciple ("Schülerin") of his, and now condemned her in terms of gender stereotypes, at least in his handwritten comments on the copy of her dissertation and theses which she had sent him-as he had turned to anti-Jewish stereotypes, even in public, when his former disciple Gumprecht had criticized him (see note 93 above and related text): "Getting pregnant fits girls and women better than writing about pregnancies." ("Das Schwangerwerden steht ihnen [i.e. "Weibern und Mädchen"] . . . besser an als über
}

Schwangerschaften zu schreiben." He added in Latin: "Conceiving children is appropriate for a girl, not books." ("Non libris, pueris gignendis apta puella est.") On Charlotte Heidenreich, née Heiland, also named von Siebold (1788-1859) and her parents, see Hans Körner, Die Würzburger Siebold: eine Gelehrtenfamilie des 18. und 19. Jahrhunderts (Deutsches Familienarchiv, vol. 34-35), Neustadt an der Aisch, Degener, 1967, pp. 113-53. The cases attended by her in the Göttingen lying-in hospital were: AUFK Gö, A 7 (Tagebuch, vol. 13), no. 128: "Partus naturalis.... [Ich ließ] Fräulein v[on] Siebold die Zange bloß zum Versuch anlegen und wieder herausnehmen. Sie machte das Anlegen recht brav, ungeachtet sie erst wenige Stunden Unterricht gehabt hatte." no. 117: "Ich ließ ... Fräulein v[on] Siebold die Zange anlegen, welche sie auch recht brav einbrachte, und mit c[ir]c[a] 6 Tract[ionen] den Kopf glücklich zur Welt brachte." "Op[era]t[ionem] fec[it] d[omi]na juven[is] de Siebold Darmstadiensis, artis obstetriciae studiosa." no. 125: "[Sie brachte die Zange] geschickt [ein]", 


\section{The Practice of Practical Education}

communities, were to be overcome by his lessons. ${ }^{147}$ Medical students, on the other hand, were supposed to be much more accustomed to learning by means of books and words, not by practical experience.

As regards the great emphasis that Osiander put on expertise in the use of the forceps, his reasoning may have been that physicians and surgeons were called more frequently to emergencies than to normal births. ${ }^{148}$ It is questionable, however, whether effective use of this instrument could be learnt by seeing it used by the professor, exercising a couple of times on the phantom, and trying it out once or twice on a real patient. There is indirect evidence that Osiander himself had doubts, for in his case book he occasionally noted with surprise that a student had introduced the forceps well, although he had practised for only a limited time. ${ }^{149}$ And in his textbook, Osiander stressed that use of the forceps had to be learnt thoroughly: you "should familiarize yourself meticulously with ... the skilful application of the forceps and acquire the required degree of dexterity, before you start to practise midwifery on your own"; otherwise, you "may be exposed to the humiliating reproach that, in the hand of an ignorant and clumsy person, the forceps are like a sharp knife in that of a child". 150

There is no doubt that a maternity hospital like the one at the University of Göttingen allowed more practical training than had previously been possible, and Osiander proudly told the Hanover government in 1801: "Perhaps, no professor before me has ever insisted to such a degree on giving students of obstetrics so much practical experience as well as a thorough theoretical education." 151 All the same, the great majority of medical students probably had much to learn on the job, after their years at university. Osiander hoped to build the foundation for such a continuing education by the enlightened principles expounded in his lectures and demonstrated in the obstetric activity of his hospital. Discussing in his textbook "the right way of learning the obstetric art", he actively promoted the model he practised in Göttingen: first oral and written instruction was required, then practical instruction had to follow, and finally the student needed to "try the art himself" at a maternity hospital, "under the guidance of the teacher". Although humility was not one of his most noticeable traits, Osiander added that a man will become a "master of the art" only by exercising on his own in private practise, and by continued lifelong study. ${ }^{152}$

\footnotetext{
${ }^{147}$ Osiander wanted midwife apprentices to be young, and was concerned that older women who had already borne many children might have "soaked up many a dangerous prejudice and superstition from ignorant midwives"; Osiander, Lehrbuch der Hebammenkunst, op. cit., note 49 above, pp. 15-16.

${ }^{148}$ This was true in Germany during the eighteenth and the nineteenth centuries, whereas in England menmidwives were frequently called to normal births in the second half of the eighteenth century; see Seidel, op. cit. note 18 above, pp. 337-39, 343-49; Wilson, op. cit. note 36 above, pp. 167-8, 175-78.

${ }^{149}$ Such was the case of his junior colleague, Professor Wardenburg, after two days of private instruction with Osiander; AUFK Gö, A 3 (Tagebuch, vol. 7), no. 131 (1802). Cf. his remarks on Charlotte von Siebold's and Kübler's first attempts, notes 146, 123 above and related text.
}

${ }^{150}$ Osiander, Grundriss, op. cit., note 29 above, vol. 2, pp. 69-70: "[Man soll] die Anwendung der Zange nicht für eine unbedeutende Sache halten, sondern sich erst mit ihrer bestimmten und geschickten Einrichtung und Anwendung genau bekannt machen und sich den nötigen Grad der Fertigkeit erwerben ..., ehe man sich selbst überlassen seine geburtshülfliche Praxis anfängt, damit man sich nicht den schimpflichen Vorwurf zuziehet, die Zange sei bei dem Unwissenden und Ungeschickten ein spitziges Messer in der Hand eines Kindes ....".

${ }^{151}$ UnivA Gö, Kur. 4731, fol. 34: "Vielleicht hat nie ein Lehrer vor mir so sehr darauf gesehen, die Studierende der Entbindungskunst neben gründlicher Theorie praktisch zu bilden, als ich ...".

${ }^{152}$ Osiander, Grundriss, op. cit., note 29 above, vol. 1, pp. 11-12: "Von der rechten Erlernungsart der Entbindungskunst"; "Hat man erst seine Kunst unter 


\section{Jürgen Schlumbohm}

The hospital at Göttingen offered the students no more than an initial opportunity at trying the art themselves. Hands-on practical experience with deliveries was a scarce resource, and only a small amount could be allocated to each. In spite of that, governments, professors and students were convinced that such experience made a crucial difference in forming capable physicians. Whether students had more opportunities in this area in big hospitals, such as those in Vienna or in Dublin, remains to be explored. No male students were allowed in the huge lying-in hospital of Port-Royal until the late nineteenth century, and it may well be that in other places, too, most deliveries were attended by midwives, not doctors or students, during the late eighteenth and early nineteenth centuries. ${ }^{153}$

Leitung des Lehrers an solchen Anstalten [i.e. "Entbindungsanstalten, Entbindungshospitäler, Gebärhäuser etc."] selbst versucht, so muss eigene Übung in der Privat-Praxis bei lebenslänglich fortgesetztem Studium den Meister in der Kunst hervorbringen."

${ }^{153}$ Cf. note 73 above. 